\title{
The oxygen isotopic composition of phytolith assemblages from tropical rainforest soil tops (Queensland, Australia): validation of a new paleoenvironmental tool
}

\author{
A. Alexandre ${ }^{1}$, J. Crespin ${ }^{1}$, F. Sylvestre ${ }^{1}$, C. Sonzogni ${ }^{1}$, and D. W. Hilbert ${ }^{1,2}$ \\ ${ }^{1}$ CEREGE, UMR7330, Aix-Marseille Université, CNRS, IRD, Europôle de l'Arbois, BP80, 13545 Aix en Provence, \\ Cedex 04, France \\ ${ }^{2}$ CSIRO Ecosystem Sciences, Tropical Forest Research Centre, P.O. Box 780, Atherton, QLD 4883, Australia
}

Correspondence to: A. Alexandre (alexandre@ cerege.fr)

Received: 21 April 2011 - Published in Clim. Past Discuss.: 27 May 2011

Revised: 28 October 2011 - Accepted: 9 January 2012 - Published: 22 February 2012

\begin{abstract}
Phytoliths are micrometric particles of amorphous silica that form inside or between the cells of higher plant tissues throughout the life of a plant. With plant decay, phytoliths are either incorporated into soils or exported to sediments via regional watersheds. Phytolith morphological assemblages are increasingly used as proxy of grassland diversity and tree cover density in inter-tropical areas. Here, we investigate whether, along altitudinal gradients in northeast Queensland (Australia), changes in the $\delta^{18} \mathrm{O}$ signature of soil top phytolith assemblages reflect changes in mean annual temperature (MAT) and in the oxygen isotopic composition of precipitation $\left(\delta^{18} \mathrm{O}_{\text {precipitation }}\right)$, as predicted by equilibrium temperature coefficients previously published for silica. Oxygen isotopic analyses were performed on 16 phytolith samples, after controlled isotopic exchange (CIE), using the IR Laser-Heating Fluorination Technique. Long-term mean annual precipitation (MAP) and MAT values at the sampled sites were calculated by the ANUCLIM software. $\delta^{18} \mathrm{O}_{\text {precipitation estimates were }}$ calculated using the Bowen and Wilkinson (2002) model, slightly modified. An empirical temperature-dependant relationship was obtained: $\Delta^{18} \mathrm{O}_{\text {wood phytolith-precipitation }}$ $(\%$ vs. VSMOW $)=-0.4( \pm 0.2) t\left({ }^{\circ} \mathrm{C}\right)+46( \pm 3)\left(R^{2}=0.4\right.$, $p<0.05 ; n=12$ ). Despite the various unknowns introduced

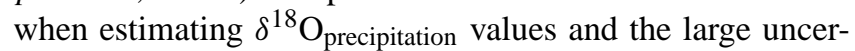

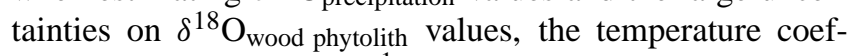
ficient $\left(-0.4 \pm 0.2 \%{ }^{\circ} \mathrm{C}^{-1}\right)$ is in the range of values previously obtained for natural quartz, fresh and sedimentary
\end{abstract}

diatoms and harvested grass phytoliths (from -0.2 to $-0.5 \% 0^{\circ} \mathrm{C}^{-1}$ ). The consistency supports the reliability of $\delta^{18} \mathrm{O}_{\text {wood phytolith }}$ signatures for recording relative changes in

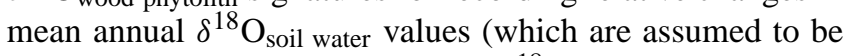
equivalent to the weighted annual $\delta^{18} \mathrm{O}_{\text {precipitation values in }}$ rainforests environments) and MAT, provided these changes were several $\% \circ$ and/or several ${ }^{\circ} \mathrm{C}$ in magnitude.

\section{Introduction}

Phytoliths are micrometric particles $(<60-100 \mu \mathrm{m}$ of diameter) of amorphous silica that form within a matter of hours to days (Perry et al., 1987) inside or between the cells of higher plant tissues throughout the life of a plant. With plant decay, phytoliths are either incorporated into soils or exported to sediments via regional watersheds. Phytolith morphological assemblages are increasingly used as proxy of grassland diversity and tree cover density in inter-tropical areas (e.g. Alexandre et al., 1998; Boyd et al., 2005; Bremond et al., 2005a,b, 2008a,b Piperno, 2006; Lentfer and Torrence, 2007; Neuman et al., 2009). In parallel, pioneering studies of the oxygen isotope composition $\left(\delta^{18} \mathrm{O}\right)$ of phytoliths have demonstrated that in non-transpiring grass stem tissues, the equilibrium fractionation between water and phytolith is temperature-dependent (Shahack-Gross et al., 1996; Webb and Longstaffe, 2000, 2002, 2003, 2006). The obtained temperature coefficient is $-0.33 \% 0^{\circ} \mathrm{C}^{-1}$ (recalculated from 
Shahack-Gross et al., 1996), in the -0.2 to $-0.5 \% 0^{\circ} \mathrm{C}^{-1}$ range of temperature coefficients previously measured for biogenic silica (diatom frustules) and quartz (Clayton et al., 1972; Matsuhisa et al., 1979; Juillet-Leclerc and Labeyrie, 1987; Shemesh et al., 1992; Sharp and Kirschner, 1994; Brandriss et al., 1998; Moshen et al., 2005; Dodd and Sharp, 2010; Crespin et al., 2010). Those studies also evidenced that in transpiring tissues, ${ }^{18} \mathrm{O}$ enrichment of sap water increases with the inverse of relative humidity, which limits the use of the $\delta^{18} \mathrm{O}$ signature of phytoliths from grass leaves as a function of temperature and the isotopic composition of soil water $\left(\delta^{18} \mathrm{O}_{\text {soil water }}\right)$ (Webb and Longstaffe, 2000, 2002, 2003, 2006). These calibration studies, although extremely useful for our understanding of the temperature and soil-water $\delta^{18} \mathrm{O}$ signals carried by phytoliths, have not lead to paleoenvironmental reconstructions due to the fact that phytoliths from both transpiring and non-transpiring grass tissues are not morphologically distinguishable.

In this paper, we explore if the $\delta^{18} \mathrm{O}$ signature of rainforest phytolith assemblages (Fig. 1.), which consist of more than $80 \%$ of a single phytolith type produced in non-transpiring wood (Alexandre et al., 1997; Runge, 1999; Bremond et al., 2005b), can be used as climate proxy. We investigate whether, along altitudinal gradients in northeast Queensland (Australia), changes in the $\delta^{18} \mathrm{O}$ signature of soil top phytolith assemblages reflect changes in mean annual temperature (MAT) and in the oxygen isotopic composition of precipitation $\left(\delta^{18} \mathrm{O}_{\text {precipitation }}\right)$, as predicted by equilibrium temperature coefficients previously published for silica.

With the overall objectives of paleoenvironmental reconstructions, we consider the soil top phytolith assemblages as modern reference assemblages for the following reasons: (1) in northeast Queensland, lake catchments are small (e.g. Haberle, 2005; Kershaw et al., 2007) and the majority of phytoliths found in lake sediments is expected to come from soil tops; (2) the time span recorded by soil top phytolith assemblages should fit with the time span recorded by fossil phytolith assemblages sampled from sedimentary cores. Indeed, the weak concentration of phytoliths in rainforest soil tops (a few \%o in weight, Alexandre et al., 1997) and in the suspended load of tropical rivers (less than 5\%o in weight, Carry et al., 2005) suggests that the mean phytolith concentration in lake sediments is also on the order of a few $\% o$ in weight. Taking into account the amount of phytoliths required for $\delta^{18} \mathrm{O}$ analyses (several $\mathrm{mg}$ ) and using the lake sediment accumulation rates commonly observed in Queensland rainforest environments (cm/100 yr; e.g. Haberle, 2005; Rieser and Wust, 2010), the fossil phytolith assemblages provided using sampling intervals of several centimeters in lake sediment cores should encompass 100 s of years. Mean age of 100s of years was measured for bulk organic matter (OM) from one of the soil top samples investigated here $\left({ }^{14} \mathrm{C}\right.$ mean age of sample \#18 was cal. $605 \pm 36 \mathrm{yr}$ BP; AMS $-{ }^{14} \mathrm{C}$ UCIAMS \#75077, calibrated after Danzeglocke et al., 2011), and can be reasonably expected for phytoliths (Alexandre et al.,

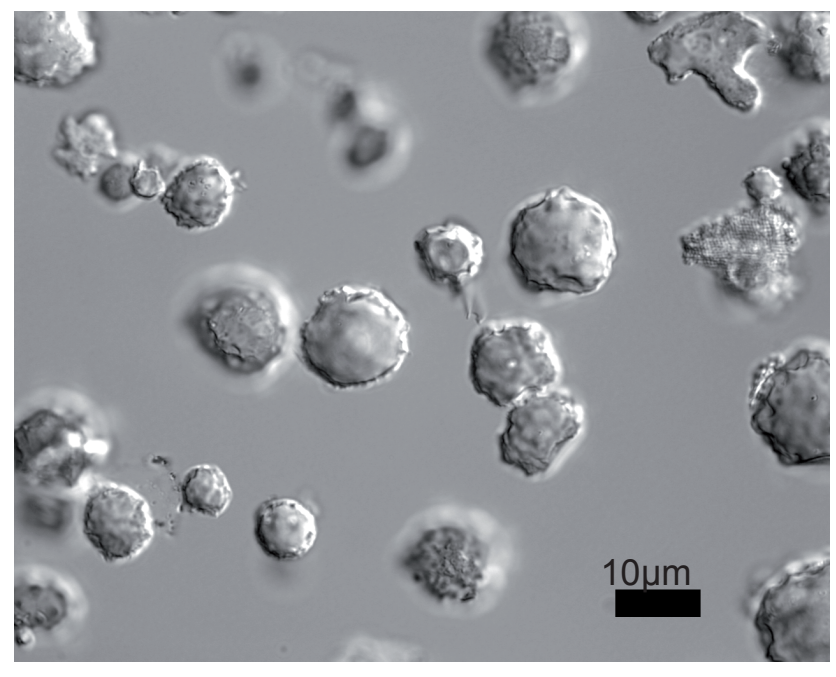

Fig. 1. Phytolith assemblage typical of rainforest, dominated by the "globular granulate" phytolith type.

1999); and (3) soil top phytolith assemblages of hundreds of years may have been subject to early selective dissolution (Alexandre et al., 1997), alike fossil phytolith assemblages.

In the absence of measured $\delta^{18} \mathrm{O}_{\text {precipitation }}$ and $\delta^{18} \mathrm{O}_{\text {soil }}$ values, and in order to limit the uncertainty associated with $\delta^{18} \mathrm{O}_{\text {precipitation }}$ estimates, we deliberately chose to sample 16 sites along 4 altitude gradients with close environmental characteristics: (1) podzolic soils are developed at the expense of granitic and metamorphic parent-rocks; (2) all sites (except site 21) are covered by a closed rainforest with a very low range of vapor pressure deficit for much of the time (0$0.2 \mathrm{kPa}$; Hutley et al., 1997); (3) most of the precipitation comes from air masses brought by the dominant NW monsoonal winds; (4) altitude is the main control on temperature (DASETT, 1986) and presumably on $\delta^{18} \mathrm{O}_{\text {precipitation and }}$ $\delta^{18} \mathrm{O}_{\text {soil }}$ values variations.

Phytolith $\delta^{18} \mathrm{O}$ values, measured using the IR LaserHeating Fluorination Technique, were correlated with mean annual temperature (MAT) values obtained using the ANUCLIM software (McMahon et al., 1995) and with

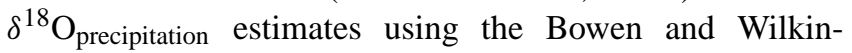
son (2002) model slightly modified. Although this approach requires to introduce various unknowns and to deal with large uncertainties, it shows that $\delta^{18} \mathrm{O}_{\text {wood phytolith values from the }}$ leeward slopes record the modern combination of weighted annual $\delta^{18} \mathrm{O}_{\text {precipitation }}$ values and MAT.

\section{Study area}

\subsection{Geomorphic features}

The Wet Tropical rainforests of Queensland extend from $16^{\circ} 27^{\prime}$ to $17^{\circ} 38^{\prime} \mathrm{S}$, and from $145^{\circ} 19^{\prime}$ to $145^{\circ} 51^{\prime} \mathrm{W}$ and have been protected as a world heritage area since 1988 . The main 
Table 1. Location of the sampled sites and associated climate parameters provided by the ANUCLIM software (D. coast: distance from the coast; Alt: altitude; Max Alt: mean maximum altitude crossed by air masses; MAT: mean annual temperature; MAP: mean annual precipitation; H: relative humidity). Rainforest types from Tracey (1982). $\delta^{18} \mathrm{O}_{\text {precipitation }}$ values are estimated from Eqs. (7) and (8) slightly modified after Bowen and Wilkinson (2002).

\begin{tabular}{|c|c|c|c|c|c|c|c|c|c|c|c|c|c|c|}
\hline $\begin{array}{l}\text { Sample } \\
\text { \# }\end{array}$ & Transect & $\begin{array}{l}\text { Latitude S } \\
\text { DD }\end{array}$ & $\begin{array}{l}\text { Longitude E } \\
\text { DD }\end{array}$ & $\begin{array}{l}\text { D. coast } \\
\mathrm{m}\end{array}$ & $\begin{array}{r}\text { Alt } \\
\text { (ma.s.1.) }\end{array}$ & $\begin{array}{l}\text { Max Alt } \\
\text { (ma.s.1.) }\end{array}$ & $\begin{array}{l}\text { MAT } \\
\left({ }^{\circ} \mathrm{C}\right)\end{array}$ & $\begin{array}{l}\text { Error* } \\
\left({ }^{\circ} \mathrm{C}\right)\end{array}$ & $\begin{array}{l}\text { MAP } \\
(\mathrm{mm})\end{array}$ & $\begin{array}{l}\text { Error* } \\
(\mathrm{mm})\end{array}$ & $\begin{array}{r}\mathrm{H} \\
(\%)\end{array}$ & $\begin{array}{l}\text { Rainforest } \\
\text { type }\end{array}$ & $\begin{array}{l}\delta^{18} \mathrm{O}_{\text {precipitation }} \\
(\% \circ \text { vs. V-SMOW })\end{array}$ & Uncertainty* \\
\hline 9 & Bartle frere & 17.28 & 145.62 & 70 & 770 & 1600 & 19.8 & 0.2 & 1832 & 275 & 82 & 1 & -8.97 & 0.8 \\
\hline 38 & Bartle frere & 17.38 & 145.79 & 40 & 1113 & 1600 & 17.9 & 0.2 & 4082 & 612 & 100 & $8 / 9$ & -7.86 & 1.0 \\
\hline 36 & Bartle frere & 17.38 & 145.79 & 40 & 1222 & 1600 & 17.4 & 0.2 & 4603 & 690 & 100 & $8 / 9$ & -7.64 & 1.1 \\
\hline 35 & Bartle frere & 17.38 & 145.80 & 40 & 1283 & 1600 & 17 & 0.2 & 4942 & 741 & 100 & $8 / 9$ & -7.52 & 1.2 \\
\hline 21 & Palmerston & 17.57 & 145.83 & 30 & 190 & 190 & 22.7 & 0.2 & 3333 & 500 & 92 & 24 & -3.67 & 0.0 \\
\hline 24 & Palmerston & 17.61 & 145.77 & 30 & 405 & 405 & 21.7 & 0.2 & 3154 & 473 & 94 & $1 / 2$ & -4.48 & 0.1 \\
\hline 19 & Palmerston & 17.59 & 145.62 & 40 & 810 & 810 & 19.6 & 0.2 & 2516 & 377 & 92 & $5 \mathrm{a}$ & -5.30 & 0.2 \\
\hline 18 & Palmerston & 17.53 & 145.58 & 40 & 950 & 950 & 19 & 0.2 & 2281 & 342 & 91 & $5 a$ & -5.58 & 0.3 \\
\hline 17 & Palmerston & 17.52 & 145.57 & 40 & 1050 & 1050 & 18.2 & 0.2 & 2583 & 387 & 95 & 24 & -5.78 & 0.3 \\
\hline 16 & Mt. Edith & 17.13 & 145.63 & 70 & 670 & 1500 & 20.4 & 0.2 & 1569 & 235 & 72 & 1 & -8.01 & 0.6 \\
\hline 15 & Mt. Edith & 17.11 & 145.62 & 70 & 750 & 1500 & 20 & 0.2 & 1700 & 255 & 78 & $8 / 9$ & -8.17 & 0.6 \\
\hline 14 & Mt. Edith & 17.11 & 145.62 & 70 & 840 & 1500 & 19.5 & 0.2 & 1941 & 291 & 82 & $8 / 9$ & -8.35 & 0.7 \\
\hline 11 & Mt. Edith & 17.09 & 145.62 & 70 & 1150 & 1500 & 18 & 0.2 & 3083 & 462 & 96 & $8 / 9$ & -8.97 & 0.8 \\
\hline 28 & N. Cairns & 16.47 & 145.33 & 30 & 70 & 70 & 24.1 & 0.2 & 2040 & 306 & 67 & $1 / 2$ & -3.68 & 0.0 \\
\hline 29 & N. Cairns & 16.52 & 145.39 & 30 & 210 & 210 & 23.2 & 0.2 & 1758 & 264 & 65 & $16 \mathrm{~g}$ & -4.10 & 0.1 \\
\hline 33 & N. Cairns & 16.81 & 145.49 & 30 & 600 & 600 & 22.1 & 0.2 & 1500 & 225 & 71 & $1 \mathrm{~b}$ & -4.88 & 0.2 \\
\hline
\end{tabular}

* Calculations detailed in Sect. 4.5.

distribution of rainforests in northern Queensland straddles three geologic and geomorphic regions that are NW-SE or $\mathrm{N}-\mathrm{S}$ oriented (Fig. $2 \mathrm{a}$ and $\mathrm{b}$ ): the basaltic tablelands, with an average altitude of $760 \mathrm{~m}$ a.s.l. on the west; the alluvial, granitic, and metamorphic lower coastal belt (0-900 m a.s.l.) on the east that includes a coastal plain and a coastal range; and the intermediate granitic and metamorphic eastern highlands with isolated peaks up to $1545 \mathrm{~m}$ a.s.l. (Mt. Belleden Ker) and 1622 ma.s.l. (Mt. Bartle Frere). The eastern highlands and the tablelands belong to the Great Dividing Range. Red or yellow loams, red podzolic soils, xanthozems, and krasnozems were developed throughout the weathering of metamorphic rocks, granite, and basalts.

\subsection{Climate features}

The region is located at the southern limit of an area that is influenced by the Australian Summer Monsoon (ASM). The climate pattern is controlled by the position of the Intertropical Convergence zone (ITCZ) and the monsoon circulation. Over $80 \%$ of mean annual precipitation falls during the November-March interval, supplied by NW monsoonal winds during the earlier phase of the ASM, by S-E trade winds during the later phase of the ASM (Godfred-Spenning and Reason, 2002) and by occasional cyclones. In the NWSE oriented eastern highlands, there is a very pronounced orographic influence with higher precipitation averages centred around the highest peaks and their eastern slopes, windward to the moist prevailing SE airstream. Mean annual precipitation reaches $4000 \mathrm{~mm} \mathrm{yr}^{-1}$ along the coast, increasing with elevation to reach $11000 \mathrm{~mm} \mathrm{yr}^{-1}$ at Mt. Bartle Frere, and falls dramatically inland $\left(1200 \mathrm{~mm} \mathrm{yr}^{-1}\right.$ on the western
Tableland) (Fig. 2c). At higher ranges (from $1000 \mathrm{~m}$ a.s.1.), fog and orographic cloud layers shroud the summits of the mountains and maintain moist conditions throughout the year. Fog deposition accounts for approximately $40 \%$ of the water reaching the forest floor (Hutley et al., 1997). The amount of water derived from the canopy interception, also called "cloud stripping" by these high-altitude "cloudforests", can account for $66 \%$ of precipitation during the dry season (McJannet et al., 2007a,b). Coastal humidity averages $78 \%$ in the summer but often reaches values higher than $90 \%$. Mean annual temperature (MAT) exceeds $24^{\circ} \mathrm{C}$ along the coast and falls to below $21^{\circ} \mathrm{C}$ on the tableland, and to below $17^{\circ} \mathrm{C}$ in the highest ranges (DASETT, 1987; Moss and Kershaw, 2000; Godfred-Spenning and Reason, 2002; Robertson et al., 2005).

\subsection{Vegetation features}

Rainforests of the wet tropics of Queensland are classified into 27 structural categories that contain more than 3000 plant species from 210 families (Tracey, 1982; Webb and Tracey, 1994). Soils were sampled from areas that support seven rainforest categories (Table 1), numbered and described by Tracey (1982) as follows: Type 16g (medium and low woodlands) occurs in wet and moist zones on metamorphic foothills. Canopies average $15-20 \mathrm{~m}$. Eucalyptus and Acacia species are common. The ground layer is rich in grasses (e.g. Imperata cylindrica). Type 1 (complex mesophyll vine forests) occurs on the highly fertile basaltic and alluvial soils on the tropical humid lowlands. The canopy level reaches $20-40 \mathrm{~m}$. Most of the trees are evergreens. Woody lianes, vascular epiphytes, tree palms, and fleshy 


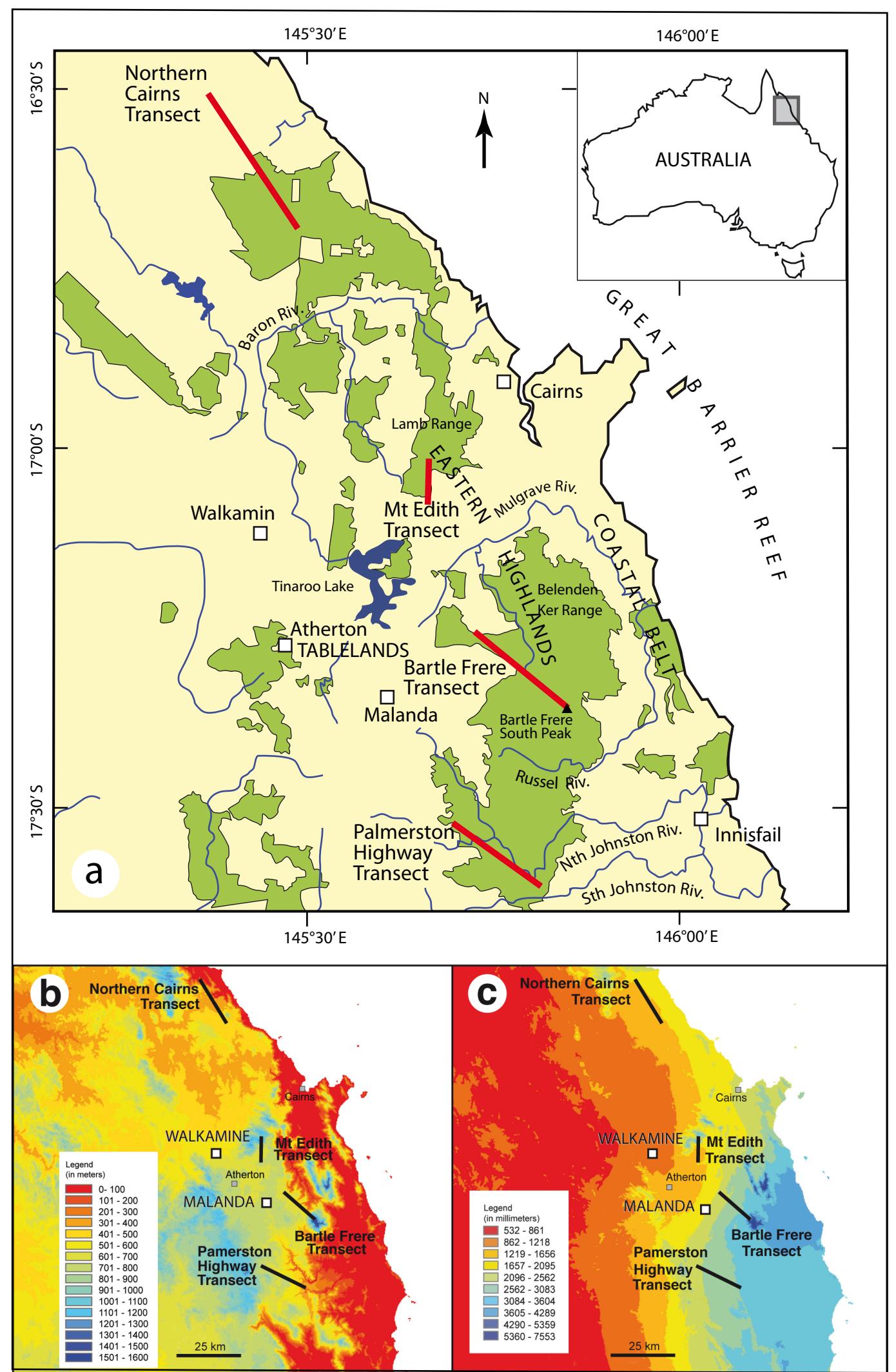

Fig. 2. (a) Location of the rainforests area (in green) in the Wet Tropics of Queensland. (b) Altitude and (c) mean annual precipitation (MAP) maps generated by the ANUCLIM software (McMahon et al., 1995). Sampled transects and stations of Malanda and Walkamine for which measured $\delta^{18} \mathrm{O}_{\text {precipitation }}$ data is available are positioned. 
herbs with wide leaves (e.g. zingibers and aroids) are prominent. Type 2 (mesophyll vine forests) occurs on granite and schist shallow soils of low to medium fertility, below $400 \mathrm{~m}$ a.s.l. The canopy is $30 \mathrm{~m}$ high. The forest has a combination of structural features intermediate between those of complex mesophyll and simple notophyll types. Type 5 (complex notophyll vine forests) occur on the tableland, on the wet uplands and highlands, and on the basic volcanic soils. The canopy is $20-45 \mathrm{~m}$ high. Robust woody lianes and epiphytes, aroids and zingibers are conspicuous life forms. Dense ground ferns, tree ferns, and palms are present (type 5a). Type 8 (simple notophyll vine forest) occurs between 400 and $1000 \mathrm{~m}$ a.s.l. on granitic ranges. Canopy is 23-33 m high. Tree palms are often locally common. Ground ferns are abundant. Canopy is stunted and wind-sheared on exposed ridges, grading into type 9. Type 9 (simple microphyll vine-fern forest) occurs between 800 and $1300 \mathrm{~m}$ a.s.l., on granite soils of the cloudy wet highlands. The canopy is $10-25 \mathrm{~m}$ high, and the trees are evergreens. Only two or three layers are noticeable. Epiphytes are common. A dense ground layer is characteristic and composed of ferns, palms, and herbs. Forests of this type are also called "cloud" or "wet montane" forests. Type 24 (cleared areas) is made of complex mesophyll vine forest fragments, sugar-cane in the lowlands, and mixed farming in the uplands. Sampling was performed under the forest remnants.

\section{Materials}

Sixteen samples were collected from poorly drained podzolic soils developed at the expense of granitic and metamorphic parent-rocks, along four altitudinal transects from 70 to 1283 m a.s.l. (Table 1, Figs. 2 and 3). The sampling method consisted of collecting individual sub-samples of the upper $2 \mathrm{~cm}$ of the soil humic horizon (litter excluded), at random intervals, over an area of $5 \times 5 \mathrm{~m}$. Sub-samples were mixed together.

Three transects where samples were collected are located in the eastern highlands, east Atherton, while the fourth transect (Northern Cairns) is located on the coastal belt. The "Bartle Frere" transect is located on the North-Western slope of Bartle Frere South Peak (1615 ma.s.l.), above Russell River oriented NW-SE when its upstream section crosses the upper rainforest area. All of the sampled points are leeward relative to the dominant S-E trade winds. The "Palmerston Highway" transect is located in the eastern section of the eastern highlands, above the Johnston River valley (NW-SE). The sites sampled are windward to the dominant S-E trade winds. The "Mt. Edith" transect is located on the southern slope of Mount Edith (1149 m a.s.l.). The sampled sites are windward, but the S-E trades first pass over the Bellenden Ker range (maximum altitude of $1545 \mathrm{~m}$ a.s.l., mean altitude of $1100 \mathrm{~m}$ a.s.1.) before reaching the tablelands and flowing up to Mt. Edith. The "Northern Cairns" transect is located on

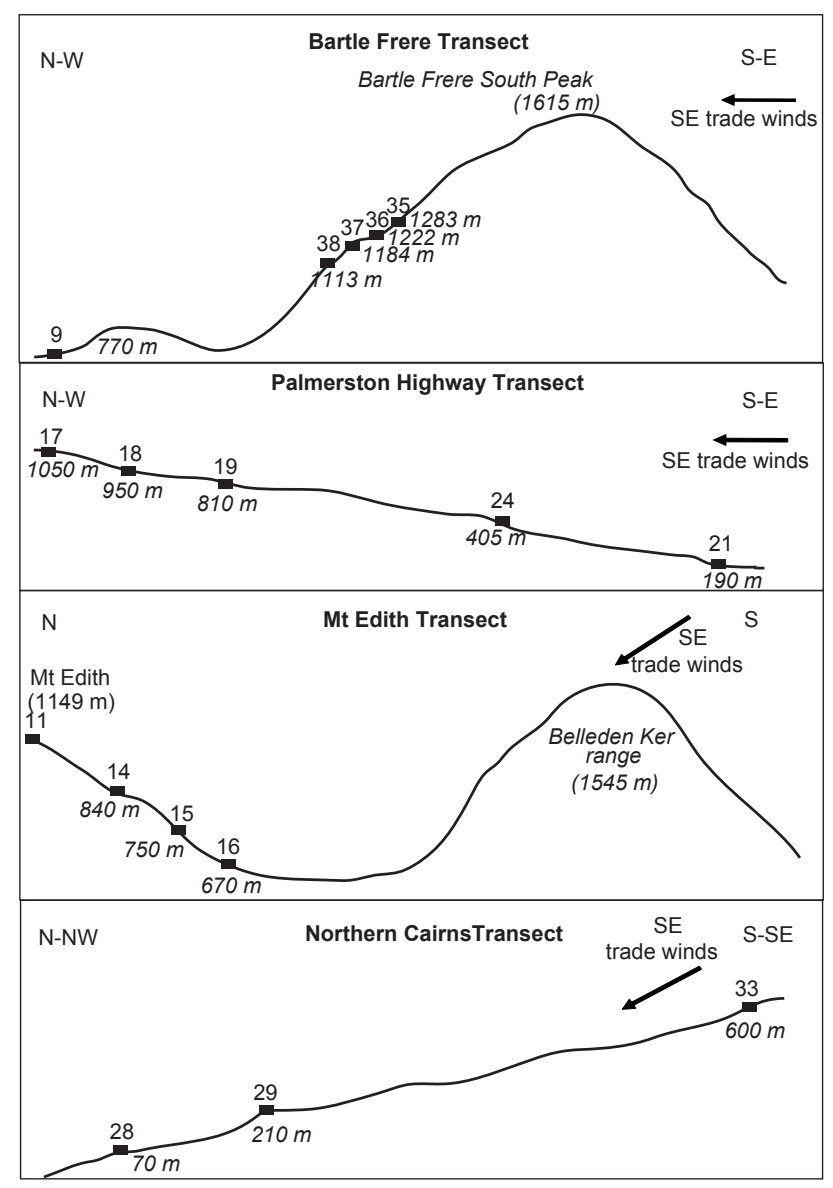

Fig. 3. The four sampled transects: topography and location relatively to the dominant S-E trade winds. Numbers refer to the sampled sites (Table 1).

the coastal belt. The sampled points are windward (Fig. 3) relative to the dominant $\mathrm{S}-\mathrm{E}$ trade winds.

Long term climate means at the sampling sites (Table 1) were obtained from regional, digital maps of bioclimatic variables that were created using the ANUCLIM software (McMahon et al., 1995), which uses a Digital Elevation Model (DEM) and meteorological data from a large number of stations over variable time periods (several decades) to estimate the climate variables for each grid cell in the DEM $\left(0.1 \mathrm{~km}^{2}\right)$.

\section{Methods}

\subsection{Phytolith chemical extraction}

Phytoliths were extracted from $20 \mathrm{~g}$ of dry soil slightly crushed and sieved at $2 \mathrm{~mm}$, after which the following steps were applied (Kelly, 1999; Crespin et al., 2008): (1) dissolution of carbonates using $\mathrm{HCl}(1 \mathrm{~N})$; $(2)$ an iron oxide reduction performed with trisodium citrate $\left(\mathrm{C}_{6} \mathrm{H}_{5} \mathrm{Na}_{3} \mathrm{O}_{7}\right)$ at $88.4 \mathrm{gl}^{-1}$ and $1 \mathrm{~g}$ of sodium dithionite $\left(\mathrm{Na}_{2} \mathrm{O}_{4} \mathrm{~S}_{2}, \mathrm{H}_{2} \mathrm{O}\right)$; 
(3) the oxidation of organic matter performed using $\mathrm{H}_{2} \mathrm{O}_{2}$ (30\%) until the reaction subsided; (4) a defloculation using a sodium hexametaphosphate $\mathrm{Na}\left(\mathrm{PO}_{3}\right)_{6}(5 \%)$ solution buffered at $\mathrm{pH} 7$; (5) a sieving of the samples at $60 \mu \mathrm{m}$; (6) a clay removal by sedimentation and centrifugation; (7) a densimetric separation of phytoliths carried out with a zinc bromide heavy liquid $\left(\mathrm{ZnBr}_{2}\right)$ that had a density of 2.3; and (8) drying for at least $24 \mathrm{~h}$. Steps 2 and 3 were carried out at $50^{\circ} \mathrm{C}$ as previously recommended (Crespin et al., 2008).

\subsection{Phytolith counting}

The recovered fraction was mounted on microscope slides in Canada Balsam, for counting at $600 \mathrm{X}$ magnification. More than 200 identifiable phytoliths with a diameter greater than $5 \mu \mathrm{m}$ and with a taxonomic significance were counted per sample. Repeated counting gave an error of $\pm 3.5 \%$ (SD). Phytoliths were classified following Twiss (1992), Mulholland (1989), Fredlund and Tieszen (1994), Kondo et al. (1994), Alexandre et al. (1997), Barboni et al. (1999), Runge (1999), and Bremond et al. (2008); and named using the International Code for Phytolith Nomenclature 1.0 (Madella et al., 2005). Phytolith types were categorized as follows: (1) dicotyledon tree and shrub types mainly represented by the Globular granulate type produced by the wood (Scurfield et al., 1974; Kondo et al., 1994); (2) a palm Globular echinate type; (3) grass (poaceae) types comprising Acicular, Elongate echinate, bulliform cells, and short cells types; and (4) types without taxonomic significance (unclassified). Abundances of the classified phytolith categories were expressed as a percentage of classified phytoliths, while the abundance of unclassified types was expressed as a percentage of the sum of counted phytoliths (Table 2). Two to $60 \mu \mathrm{m}$ size particles of quartz, iron oxide and charcoal, as well as larger thin remains of $\mathrm{OM}$, were sometimes recovered and hence counted (Table 2). Samples with more than $15 \%$ of OM remains were re-oxidized.

\section{$4.3 \quad \delta^{18} \mathbf{O}_{\text {silica }}$ measurements}

Phytoliths are hydrous silica particles that contain exchangeable oxygen mostly in hydroxyl groups (Labeyrie and Juillet, 1982; Perry and Keeling-Tucker, 2000). In order to evaluate the amount of exchangeable oxygen, to fix the isotopic composition, and to calculate the isotopic composition of non-exchangeable oxygen $\left(\delta^{18} \mathrm{O}_{\text {silica }}\right)$ a controlled isotopic exchange procedure (CIE) was carried out. Two aliquots of $1.6 \mathrm{mg}$ of the same sample were exchanged with vapor from two waters of a known isotopic composition (Crespin et al., 2008). Oxygen extractions were then performed using the IR Laser-Heating Fluorination Technique as described in Alexandre et al. (2006) and Crespin et al. (2008). Oxygen gas samples were directly sent to and analyzed by a dual-inlet mass spectrometer (ThermoQuest Finnigan Delta Plus). The oxygen isotopic results are expressed in the standard $\delta$-notation relative to V-SMOW. The measured $\delta^{18} \mathrm{O}$ values of each sample $\left(\delta^{18} \mathrm{O}_{\text {measured }} 1, \delta^{18} \mathrm{O}_{\text {measured } 2)}\right.$ were corrected on a daily basis using a quartz lab standard $\left(\delta^{18} \mathrm{O}_{\text {Boulangé }} 50-100 \mu \mathrm{m}=16.36 \pm 0.09 \%\right.$ ). Additionally, we checked that $\delta^{18} \mathrm{O}_{\text {measured } 1}$ and $\delta^{18} \mathrm{O}_{\text {measured } 2}$ values obtained for one to three aliquots of the phytolith lab standard MSG 40 were always in the standard deviation of the mean value measured during a long term calibration (Crespin et al., 2008). During the calibration period, replicate analyses of the international standard NBS 28 gave an average of $9.6 \pm 0.17 \%$ o ( $1 \mathrm{SD}, n=13)$. Replicate analyses of the soil top phytolith samples yielded to a reproducibility for $\delta^{18} \mathrm{O}_{\text {measured }}$ better than $\pm 0.5 \%$, except for one sample (\#19) (Table 2).

The recent inter-laboratory comparison for oxygen isotopic composition of hydrous biogenic silica has evidenced that, when the CEREGE CIE is performed, a methodological bias occurs leading to abnormally high fractionation between the vapour and the exchanged oxygen $\left(\Delta^{18} \mathrm{O}_{\text {vapour- }} \mathrm{O}_{\text {exchanged }}\right)$ (Chapligin et al., 2012). Tests were conducted to examine any possibility of systematic error: before the start of the CIE, the working standards were heated at $350{ }^{\circ} \mathrm{C}$ in order to remove possible labile organic remains that may increase the surface area of the materials; the amount of silica subjected to exchange was increased by 6 ; watervapour exchange temperature (and associated fractionation factor) was changed; time of vapour-silica exchange was increased while the volume of exchange was reduced by $1 / 3$; the rate of silica dehydration was reduced. None of these tests produced significant changes in the $\delta^{18} \mathrm{O}_{\text {measured }}$ values. The difference between the two labelled waters was reduced by $8 \%$, which did not change the $\delta^{18} \mathrm{O}_{\text {silica }}$ values either. Additionally, for two working standards (MSG60, $\mathrm{BFC})$, vapour-silica exchanges were carried out at three temperatures $\left(140^{\circ} \mathrm{C}, 200^{\circ} \mathrm{C}\right.$ (usual temperature) and $246^{\circ} \mathrm{C}$ ). Changes in $\delta^{18} \mathrm{O}_{\text {measured }}$ values were conform with those expected from the temperature-dependency of the equilibrium fractionation factors $\alpha_{\text {water-vapour }}$ and $\alpha_{\text {vapour-exchanged. }}$ The methodological bias assumed to occur during vapoursilica exchange remains unexplained but was reproducible and could be quantified. For this purpose, pooled values from Chapligin et al. (2012) were taken as true values. CEREGE $1000 \ln \alpha_{\text {vapour-O }}$ exchanged values obtained for 140 and $200^{\circ}$ were compared with $1000 \ln \alpha_{\text {vapour-O }}$ exchanged values previously obtained for diatoms exchanged at similar temperatures by Labeyrie and Juillet (1982). Difference was invariant with temperature and did not show any relationship with the measured percentage of exchangeable oxygen $\left(R^{2}=0.08\right)$ but decreased with increasing $\delta^{18} \mathrm{O}_{\text {silica }}$ values $\left(R^{2}=0.4\right.$ and 0.9 after outlier removal). The relationship was used in a first step to correct the values of

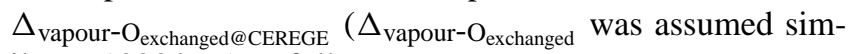
ilar to $1000 \ln \alpha$ ) as follows: 


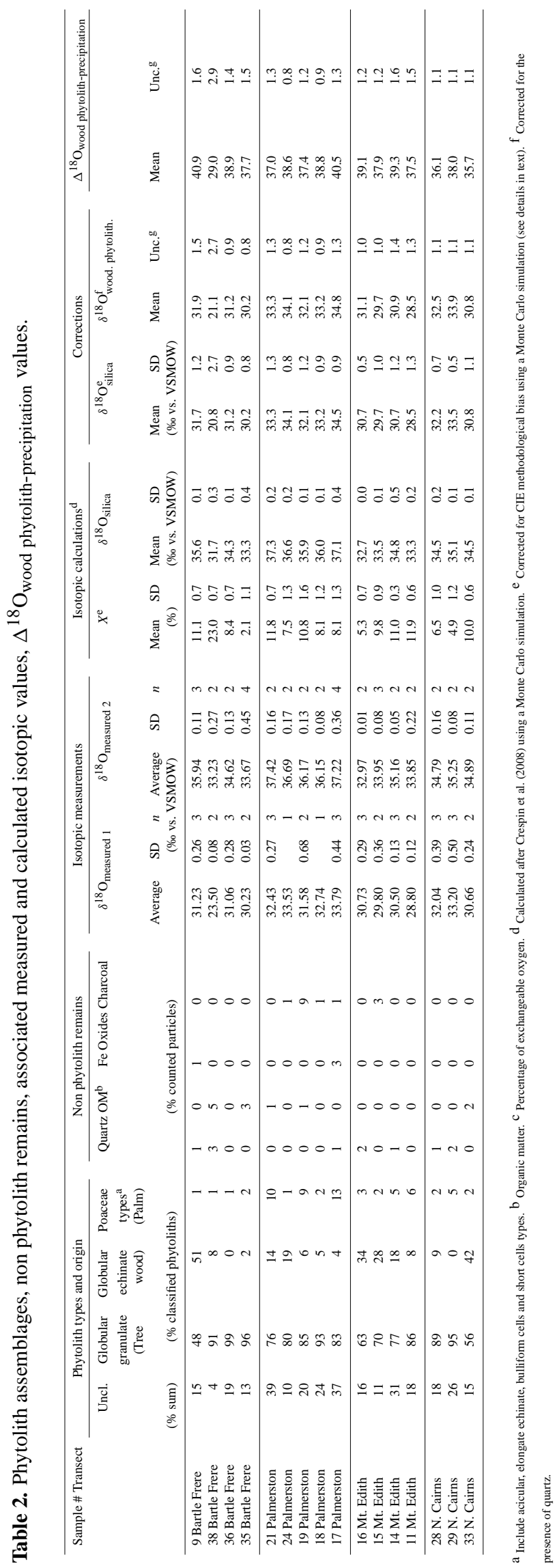


Corrected $\Delta_{\text {vapour-Oexchanged@CEREGE }}$

$$
\begin{aligned}
& =\Delta_{\text {vapour-Oexchanged, Labeyrie and Juillet (1982) }} \\
& -1.3 \times \delta^{18} \mathrm{O}_{\text {silica@CEREGE }}+78 .
\end{aligned}
$$

In a second step, the corrected $\Delta_{\text {vapour-Oexchanged }}$ values were used to correct the $\delta^{18} \mathrm{O}_{\text {silica }}$ values. The consistency of this correction was verified using an independent data set previously obtained at CEREGE for fresh water diatoms from Annecy Lake (Crespin et al., 2010). The obtained relationship between $\Delta_{\text {diatoms-lake water }}$ and temperature of the lake allowed defining a corrected relationship:

Corrected $\Delta_{\text {diatoms-lake water }}(\%$ vs. VSMOW)

$$
=-0.28( \pm 0.06) t\left({ }^{\circ} \mathrm{C}\right)+35.3( \pm 0.9)
$$

with a $R^{2}$ of 0.7 and a p-value of 0.002 , instead of

$\Delta_{\text {diatoms-lake water }}(\%$ vs. VSMOW)

$$
=-0.16( \pm 0.09) t\left({ }^{\circ} \mathrm{C}\right)+39.25( \pm 1.4) .
$$

In a $\Delta_{\text {diatomslake water }}$ vs. $t$ diagram, the obtained corrected fractionation line was shifted towards lower values of $\Delta_{\text {diatoms-lake water }}$, close to fractionation lines previously obtained for fresh water diatoms (e.g. Brandriss et al., 1998; Moschen et al., 2005; Dodd and Sharp, 2010).

Difference between corrected $\delta^{18} \mathrm{O}_{\text {silica }}$ and the pooled $\delta^{18} \mathrm{O}_{\text {silica }}$ values, however, still increased from $-0.1 \%$ (MSG60) to $+2.9 \%$ (G95), with the content in total organic carbon measured during the inter-laboratory comparison (Chapligin et al., 2012). This relationship suggested that organic remains increase the CEREGE abnormally high fractionation between the vapour and the exchanged oxygen $\left(\Delta^{18} \mathrm{O}_{\text {vapour-Oexchanged }}\right)$.

For each of the samples, mean and standard deviation (SD) of $X$ (exchangeable oxygen), $\delta^{18} \mathrm{O}_{\text {silica }}$, and corrected $\delta^{18} \mathrm{O}_{\text {silica }}$ were calculated using $R$ and a Monte Carlo simulation: $X, \delta^{18} \mathrm{O}_{\text {silica }}$ and corrected $\delta^{18} \mathrm{O}_{\text {silica }}$ were computed 10000 times, using 10000 simulated values of the variables taken into account in the equations (Crespin et al., 2008 and this section). The simulated uncertainty (SD) on corrected $\delta^{18} \mathrm{O}_{\text {silica }}$ ranged from \pm 0.5 to $1.2 \%$ o for 15 over 16 samples and reached $\pm 2.7 \%$ for one sample (\#38; Table 2 ).

\subsection{Corrections on $\delta^{18} \mathrm{O}_{\text {silica }}$ for obtaining $\delta^{18} \mathrm{O}_{\text {wood phytolith }}$}

Since some rainforest phytolith assemblages contained a small amount of 2-60 $\mu \mathrm{m}$ particles that were not wood phytoliths, corrections were made to calculate $\delta^{18} \mathrm{O}_{\text {wood phytolith }}$ values from $\delta^{18} \mathrm{O}_{\text {silica }}$ values.

- Correction for the presence of quartz particles: Weight correction was made for the amount of 2-60 $\mu \mathrm{m}$ size quartz particles given their abundance (less or equal to $3 \%$ of the counted particles in 7 samples) and the respective densities of quartz (2.6) and phytoliths (2.3). A value of $8 \%$ was attributed to quartz particles as it is in the lower range of $\delta^{18} \mathrm{O}$ values measured worldwide for detrital quartz of metamorphic origin (e.g. Garlick and Epstein, 1967; Savin and Epstein, 1970; Clayton et al., 1972; Eslinger et al., 1973; Blatt, 1986; Graham et al., 1996; Alexandre et al., 2006).

- Correction for the presence of grass phytoliths:

Phytoliths from the grass under-storey may originate from transpiring grass leaves and may have $\delta^{18} \mathrm{O}$ values slightly enriched relative to wood phytoliths. Webb and Longstaffe (2002) previously demonstrated for a grass species collected from across the North American prairies that the ${ }^{18} \mathrm{O}$ enrichment of leaf phytoliths relative to stem phytoliths increases with the inverse of relative humidity $(h)$ :

$$
\Delta^{18} \mathrm{O}_{\text {leaf silica-stem silica }}=12.5 / h-13 \text {. }
$$

As underlined by Webb and Longstaffe (2002), this relationship is very similar to that reported by Yapp (1979) for the evaporation of body fluids in land snails. It is applied here, as a general equation, to phytoliths from the under-storey grasses. According to Eq. (4), for the $0.6-1$ range of relative humidity calculated by the ANUCLIM software for the sampled sites (Table 1), leaf phytolith ${ }^{18} \mathrm{O}$ enrichment should range from 5 to $0.5 \%$. In the absence of measured data on relative humidity in the under-storey, values from Table 1 were used in Eq. (4) to correct the obtained $\delta^{18} \mathrm{O}_{\text {silica }}$ values for the presence of grass phytoliths. This correction is expected to be maximal. Indeed, in the lower canopy vapour pressure deficit is low (0-0.2 kPa; Hutley et al., 1997) and ${ }^{18} \mathrm{O}$ enrichment of leaf water should be weak, as measured in the Amazonian rainforest (Ometto et al., 2005). Moreover, grass phytolith types (Table 1) gather phytoliths from both leaves and stems; the latest being not subject to transpiration (Webb and Longstaffe, 2002).

\section{- Correction for the presence of palm phytoliths:}

To our knowledge, $\delta^{18} \mathrm{O}_{\text {water }}$ signatures in forest palm stems and leaves have never been measured. If ${ }^{18} \mathrm{O}$ enrichment is similar for palm and grass phytoliths, Eq. (4) should also be used to correct the obtained $\delta^{18} \mathrm{O}_{\text {silica }}$ values for the presence of palm phytoliths.

- No correction for the presence of unclassified phytoliths and charcoal:

Unclassified phytoliths were assumed to mainly originate from tree wood and were not corrected for. The occurrence of charcoal particles was not corrected either since charcoal is largely made of carbon and should not contribute to the oxygen yield. 
- No correction for the presence of organic matter $(O M)$ : Less or equal to $5 \%$ of thin organic matter remains, most of them with surface ranging from 100 to $200 \mu \mathrm{m}$, were counted in 5 samples (Table 2). Given the low density of organic remains $(<1)$, their weight concentration is expected to be lower than $0.2 \%$ weight.

\section{- Related uncertainties:}

Given a counting error of $\pm 3.5 \%$ (SD), the uncertainty on $\delta^{18} \mathrm{O}_{\text {wood phytolith }}$ due to quartz weight correction ranged from \pm 0.5 to $0.9 \%$ for the 7 samples where some quartz particles were counted. Uncertainties due to grass phytolith corrections ranged from \pm 0 to $0.2 \%$. Uncertainties due to palm correction were lower than $0.5 \%$, except for samples \#7 and \#11 with high content of palm phytolith types.

\subsection{Estimation of MAP, MAT and $\delta^{18} \mathrm{O}_{\text {precipitation values }}$}

Ideally, matching the time span recorded by the soil phytolith assemblages would require us to obtain, for each of the sampled sites, measurements for hundreds of years for MAP,

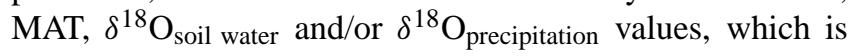
unrealistic. Therefore, estimates were made, as justified below.

Regarding atmospheric temperature, measurements back to 1910 revealed an increase of MAT of $+0.1^{\circ} \mathrm{C} / 10 \mathrm{yr}$, mostly during the second half of the 19th century in Queensland (Suppiah et al., 2001). To our knowledge there is no other continuous record of temperature from any tropical Australian site. A dendroclimatological study showed evidence of a slower increasing trend of $+1.5^{\circ} \mathrm{C}$ since the 16 th century in New Zealand (Cook et al., 2000). From these records, the assumption was made that modern long term MAT values generated by the ANUCLIM software (Table 1) should only slightly overestimate (by less than $1-2^{\circ} \mathrm{C}$ ) the mean value for the last 100s of years; this in a similar way for all the sampled sites. Given the $<0.5^{\circ} \mathrm{C}$ standard errors in monthly maximum and minimum temperature values generated by the ANUCLIM software a standard error of around $0.2{ }^{\circ} \mathrm{C}$ in MAT would be a conservative estimate (M. F. Hutchinson, personal communication; Hutchinson, 1991, 1995) (Table 1).

Regarding MAP, tree ring reconstruction from the Atherton tableland (Queensland) revealed no long trend in precipitation since 1861 (Heinrich et al., 2008). Making due allowance for varying conditions, station density and standardisation to 30 years, the predictive errors in MAP from the ANUCLIM surfaces are around 10-15\% across the continent (M. F. Hutchinson, personal communication; Hutchinson, 1991, 1995) (Table 1).

In the absence of long term $\delta^{18} \mathrm{O}_{\text {precipitation }}$ measurements close to the sampled sites, direct $\delta^{18} \mathrm{O}$ measurements could have been performed from non-evaporative surface water (e.g. river, spring water) (Lachniet and Patterson, 2009). However, given the confined sampled area, surface waters did not show sufficient variations in distance from the water source to record rapid changes in $\delta^{18} \mathrm{O}_{\text {precipitation val- }}$ ues with elevation. Weighted annual $\delta^{18} \mathrm{O}_{\text {precipitation es- }}$ timates were thus calculated using as a basis the Bowen and Wilkinson (2002) model established from the International Atomic Energy Agency-World Meteorological Organization Global Network for Isotopes in Precipitation (GNIP) database (IAEA/WMO, 1998). $\delta^{18} \mathrm{O}_{\text {precipitation val- }}$ ues are controlled by the latitude (LAT) and by the altitude (ALT). For stations located $<200$ m a.s.l. (Eq. 5) and $>200$ ma.s.l. (Eq. 6) the relationships are respectively expressed as:

$$
\begin{aligned}
& \delta^{18} \mathrm{O}_{\text {precipitation }}=-0.0051(|\mathrm{LAT}|)^{2}+0.1805(|\mathrm{LAT}|)-5.247(5) \\
& \delta^{18} \mathrm{O}_{\text {precipitation }}=-0.0051(|\mathrm{LAT}|)^{2}+0.1805(|\mathrm{LAT}|) \\
& -0.002(\text { ALT) }-5.247 \text {. }
\end{aligned}
$$

Equations (5) and (6) were slightly modified to take regional conditions into consideration. The magnitude of the altitude effect estimated as $0.002 \% \mathrm{~m}^{-1}$ a.s.l. by Bowen and Wilkinson (2002) was also measured worldwide with an uncertainty lower than $\pm 0.0005 \% \mathrm{om}^{-1}$ (Siegenthaler and Oeshger, 1980; Chamberlain and Poage, 2000; Gonfiantini et al., 2001; Lachniet and Patterson, 2002, 2009). However, in humid tropics, $\delta^{18} \mathrm{O}$ values of precipitation from air masses lifted over high mountains appear to be controlled by the cumulative rainout upwind of collecting stations (Lachniet and Patterson, 2009). At leeward stations, this rainout process leads to measured $\delta^{18} \mathrm{O}_{\text {precipitation values lower than }}$ those predicted by the altitude effect alone (Rietti-Shati et al., 2000; Longinelli et al., 2006; Lachniet and Patterson, 2009). This process is also called "shadow effect". In order to take into account such a cumulative rainout, the cumulative change in altitude ( $\triangle \mathrm{ALT}$ ) along a SE-NW transect (i.e. parallel with the trajectory of the dominant trade winds) was used to estimate $\delta^{18} \mathrm{O}_{\text {precipitation values at both windward }}$ and leeward sites (Fig. 3; Table 1). This procedure resulted in an inversed isotopic vertical gradient for the leeward slope of Mt. Bartle Frere, neglecting the role of increasing temperature as elevation decreases. This may have led to an underestimate for $\delta^{18} \mathrm{O}_{\text {precipitation values, especially at leeward low }}$ elevation sites. Additionally, in agreement with the few isotopic studies investigating the water cycle in rainforest areas, an inland ${ }^{18} \mathrm{O}$ gradient of $-0.08 \% / 100 \mathrm{~km}$ reflecting the influence of recycled continental moisture (mainly from evapotranspiration) (Salati et al., 1979; Gat and Matsui, 1991; Martinelli et al., 1996; Njitchoua et al., 1999; Lachniet and Patterson, 2002) was added (Eqs. 7 and 8). However, given the sites proximity to the coast, the inland gradient has limited impact on $\delta^{18} \mathrm{O}_{\text {precipitation values. }}$

Finally, for the $<200 \mathrm{~m}$ a.s.l. and $>200 \mathrm{~m}$ a.s.l. sites, the calculation of $\delta^{18} \mathrm{O}_{\text {precipitation values was as follows: }}$ 


$$
\begin{aligned}
\delta^{18} \mathrm{O}_{\text {precipitation }} & =-0.0051(|\mathrm{LAT}|)^{2}+0.1805(|\mathrm{LAT}|) \\
& -5.247-0.08(\mathrm{DIST})
\end{aligned}
$$

and

$$
\begin{array}{r}
\delta^{18} \mathrm{O}_{\text {precipitation }}=-0.0051(|\mathrm{LAT}|)^{2}+0.1805(|\mathrm{LAT}|) \\
-0.002(|\Delta \mathrm{ALT}|)-5.247-0.08(\mathrm{DIST})
\end{array}
$$

Uncertainty associated with the latitude parameter in Eqs. (7) and (8) is not known but should be similar for all the sites, as they are located at similar or close latitude (Table 1). At the global scale, the average difference between

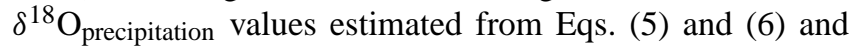
the measured values is $0.21 \%$ o $(\sigma=2.49 \%$ ) (Bowen and Wilkinson, 2002). Added to the altitude effect uncertainty $\left( \pm 0.0005 \% \mathrm{~m}^{-1}\right)$, it leads to a maximum propagated uncertainty on $\delta^{18} \mathrm{O}_{\text {precipitation }}$ estimates from Eqs. (7) and (8) ranging from 0.2 to $0.8 \%$ (Table 1 ).

Estimated weighted annual $\delta^{18} \mathrm{O}_{\text {precipitation values were }}$ compared with measured weighted seasonal $\delta^{18} \mathrm{O}_{\text {precipitation }}$ values obtained by CSIRO Land and Water during two rainy seasons in 1998 and 1999, at two stations (Malanda: $17^{\circ} 21^{\prime} \mathrm{S} ; 145^{\circ} 35^{\prime} \mathrm{E} ; 762 \mathrm{~m}$ a.s.l. and Walkamin: $17^{\circ} 08^{\prime} \mathrm{S}$; $145^{\circ} 25^{\prime} \mathrm{E}$; $594 \mathrm{~m}$ a.s.1.) located in the Atherton tablelands (Fig. 2). Those were the only measured data available for the area. Since most of the precipitation occurs during the rainy season, weighted seasonal values were expected to be close to weighted annual estimates. They were indeed very close - respectively $-8.68 \%$ and $-8.50 \%$ at Malanda and $-7.77 \%$ and $-7.85 \%$ at Walkamine - which strengthened the reliability of the $\delta^{18} \mathrm{O}_{\text {precipitation }}$ estimations.

There is no available data on long term $\delta^{18} \mathrm{O}_{\text {soil water sig- }}$ nature from the Australian rainforests. However, as those rainforests are characterized by low radiation levels due to frequent occurrence of fog and low clouds and by a low range of the vapor pressure deficit for much of the time, soil evaporation and understorey evaporation are expected to be low (Hutley et al., 1997). For comparison, $\delta^{18} \mathrm{O}_{\text {soil water val- }}$ ues measured in the Amazonian rainforest were shown to be close to $\delta^{18} \mathrm{O}_{\text {precipitation values and to lie along the local iso- }}$ topic meteoric water line (Girard et al., 2000). On steep slopes developed at the expense of granitic and metamorphic parent-rocks, shallow groundwaters may locally occur at the boundary between arenite and soils. However, if this is the case at the sample sites, local $\delta^{18} \mathrm{O}_{\text {groundwater }}$ signatures should be close to the long term $\delta^{18} \mathrm{O}_{\text {soil water }}$ values. Finally, given the conditions described above, the assumption was made that long term depth-weighted $\delta^{18} \mathrm{O}_{\text {soil water signa- }}$ tures were close to weight annual $\delta^{18} \mathrm{O}_{\text {precipitation values. }}$

\section{Results}

\subsection{Phytolith assemblages}

The abundances of tree, palm, grass, and unclassified phytolith categories are presented in Table 2. Three to four phytolith assemblages from the Bartle Frere transect (\#35, \#36, \#38), collected under the cloud forest were dominated by tree wood phytoliths (91 to $99 \%$ of classified phytoliths), while abundances of palm and grass phytoliths ranged from $0-8 \%$ and $1-2 \%$ of classified phytoliths, respectively. Tree, palm, and grass phytoliths accounted for $48 \%, 51 \%$, and $1 \%$, respectively, of classified phytoliths in the fourth assemblage (\#9) that came to the lowest site covered by a rainforest with high floristic richness. Ranges of the abundances of tree, palm, and grass phytoliths in the five assemblages from the Palmerston Highway transect were 76-93\%, 4$19 \%$, and $1-13 \%$, respectively, of classified phytoliths. In the four assemblages from the Mt. Edith transect, the abundance of tree, palm, and grass phytoliths were $63-86 \%, 8-$ $34 \%$, and $3-6 \%$, respectively, of classified phytoliths. The four phytolith assemblages from the Northern Cairns transect showed various abundances of tree, palm, and grass phytoliths: $56-95 \%, 0-42 \%$, and $2-5 \%$ of classified phytoliths, respectively. The phytolith index, D/P (the ratio of ligneous dicotyledons globular granulate, D, over short cell Poaceae phytoliths, P) was always higher than 12 in agreement with rainforests tree cover density (Bremond et al., 2005a,b).

Quartz, OM, Fe oxides and charcoal particles were present in low proportions in few samples (Table 2).

\section{$5.2 \delta^{18} \mathrm{O}_{\text {silica }}, \delta^{18} \mathrm{O}_{\text {wood phytolith }}$ and environment}

Mean, reproducibility and uncertainties of $\delta^{18} \mathrm{O}_{\text {measured } 1 \text {, }}$ $\delta^{18} \mathrm{O}_{\text {measured 2 }}$, the percentage of exchangeable oxygen, calculated $\delta^{18} \mathrm{O}_{\text {silica }}$ values corrected for the CIE methodological bias and for the presence of quartz are presented in Table 2. Corrections for the presence of grass and palm phytoliths are presented in Table 3 for comparison.

$\delta^{18} \mathrm{O}_{\text {wood phytolith }}$ values, corrected for the presence of quartz only, range from $21.1 \%$ to $31.9 \%$ or the assemblages from the Bartle Frere transect, from $32.1 \%$ to $34.8 \%$ for assemblages from Palmerston Highway, from $28.5 \%$ to $31.1 \%$ o for assemblages from the Mt. Edith transect, and from $30.8 \%$ to $33.9 \%$ o for assemblages from the Northern Cairns transect. The estimated weighted annual

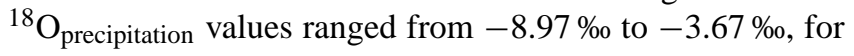
a mean annual temperature range of $17-24.1{ }^{\circ} \mathrm{C}$ and a precipitation range of $1500-4942 \mathrm{~mm} \mathrm{yr}^{-1}$ (Table 1). When all points are taken into account, no direct correlation appear between $\delta^{18} \mathrm{O}_{\text {wood phytolith }}$ values, weighted annual

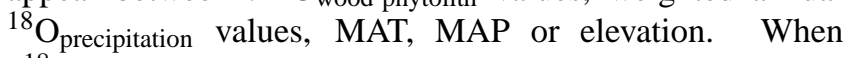
$\delta^{18} \mathrm{O}_{\text {wood phytolith }}$ values from the leeward transect of Bartle Frere are excluded (Fig. 4), a positive linear correlation with the estimated weighted annual $\delta^{18} \mathrm{O}_{\text {precipitation values }}$ 


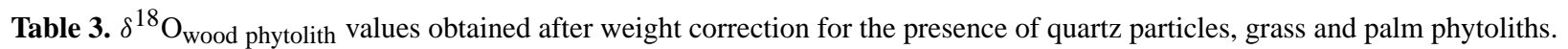

\begin{tabular}{|c|c|c|c|c|c|c|}
\hline \multirow[t]{2}{*}{$\begin{array}{l}\text { Samples \# } \\
\text { Transect }\end{array}$} & \multicolumn{2}{|c|}{$\begin{array}{l}\text { Quartz } \\
\text { corrected }\end{array}$} & \multicolumn{2}{|c|}{$\begin{array}{c}\text { Quartz } \\
\text { and grass phytoliths corrected }\end{array}$} & \multicolumn{2}{|c|}{$\begin{array}{l}\text { Quartz, grass and palm } \\
\text { phytoliths corrected }\end{array}$} \\
\hline & $\delta^{18} \mathrm{O}$ & Uncertainty* & $\delta^{18} \mathrm{O}$ & Uncertainty* & $\delta^{18} \mathrm{O}$ & Uncertainty* \\
\hline 9 Bartle Frere & 31.9 & 1.5 & 31.9 & 1.5 & 30.7 & 1.5 \\
\hline 38 Bartle Frere & 21.1 & 2.7 & 21.1 & 2.7 & 21.2 & 2.7 \\
\hline 36 Bartle Frere & 31.2 & 0.9 & 31.2 & 0.9 & 31.2 & 0.9 \\
\hline 35 Bartle Frere & 30.2 & 0.8 & 30.2 & 0.8 & 30.2 & 0.8 \\
\hline 21 Palmerston & 33.3 & 1.3 & 33.3 & 1.3 & 33.2 & 1.3 \\
\hline 24 Palmerston & 34.1 & 0.8 & 34.1 & 0.8 & 34.0 & 0.8 \\
\hline 19 Palmerston & 32.1 & 1.2 & 32.1 & 1.2 & 32.0 & 1.2 \\
\hline 18 Palmerston & 33.2 & 0.9 & 33.2 & 0.9 & 33.2 & 0.9 \\
\hline 17 Palmerston & 34.8 & 1.3 & 34.7 & 1.3 & 34.7 & 1.3 \\
\hline 16 Mt. Edith & 31.1 & 1.0 & 31.0 & 1.0 & 31.3 & 1.9 \\
\hline 15 Mt. Edith & 29.7 & 1.0 & 29.6 & 1.0 & 29.9 & 1.4 \\
\hline 14 Mt. Edith & 30.9 & 1.4 & 30.8 & 1.4 & 31.0 & 1.5 \\
\hline $11 \mathrm{Mt}$. Edith & 28.5 & 1.3 & 28.5 & 1.3 & 28.6 & 1.3 \\
\hline 28 N. Cairns & 32.5 & 1.1 & 32.4 & 1.1 & 31.9 & 1.1 \\
\hline 29 N. Cairns & 33.9 & 1.1 & 33.7 & 1.1 & 33.7 & 1.1 \\
\hline 33 N. Cairns & 30.8 & 1.1 & 30.7 & 1.1 & 28.8 & 1.1 \\
\hline
\end{tabular}

*Propagated uncertainty (see details in Sects. 4.3 and 4.4).

$\left(R^{2}=0.56\right)$ occurs, while there is still no trend either with MAT, MAP or elevation. Similar patterns are found when $\delta^{18} \mathrm{O}_{\text {wood phytolith }}$ values are additionally corrected for the presence of grass and palm phytoliths.

\subsection{The relationship between $\delta^{18} \mathrm{O}_{\text {wood phytolith values, }}$ $\delta^{18} \mathrm{O}_{\text {precipitation values, and temperature }}$}

The $\delta^{18} \mathrm{O}$ value of a mineral grown in isotopic equilibrium is a function of the temperature and the oxygen isotopic composition of the water from which it forms $\left(\delta^{18} \mathrm{O}_{\text {forming water }}\right)$, as expressed by

$\Delta^{18} \mathrm{O}_{\text {mineral-forming water }} \sim 1000 \ln \alpha=A\left(10^{6} / T^{2}\right)+B$.

Over a limited temperature range, the relationship is satisfactorily approximated by a straight line in the plot of $\ln \alpha$ vs. $t$, expressed as

$\Delta^{18} \mathrm{O}_{\text {mineral-forming water }} \sim 1000 \ln \alpha=a t+b$,

given that $\Delta^{18} \mathrm{O}_{\text {mineral-forming water }}$ is equal to $\delta^{18} \mathrm{O}_{\text {mineral }}$ $-\delta^{18} \mathrm{O}_{\text {forming water, }} \alpha$ is the fractionation factor, $A$ and $a$ are the fractionation coefficients, $B$ and $b$ are the constants, and $T$ and $t$ are, respectively, the temperature in ${ }^{\circ} \mathrm{K}$ and ${ }^{\circ} \mathrm{C}$.

In the case of rainforest phytoliths, the $\delta^{18} \mathrm{O}_{\text {wood phytolith }}$ value should be a function of the atmospheric temperature and, if there is no ${ }^{18} \mathrm{O}$ enrichment between precipitation, soil water, and xylem water, of the $\delta^{18} \mathrm{O}_{\text {precipitation value: }}$

$\Delta^{18} \mathrm{O}_{\text {wood phytolith-precipitation }}=a t+b$, given that $\Delta^{18} \mathrm{O}_{\text {wood phytolith-precipitation }}$ is equivalent to $\delta^{18} \mathrm{O}_{\text {wood phytolith }}-\delta^{18} \mathrm{O}_{\text {precipitation, }} \delta^{18} \mathrm{O}_{\text {wood phytolith }}$ is the isotopic composition of wood phytoliths (Table 3), $\delta^{18} \mathrm{O}_{\text {precipitation }}$ is the weighted annual isotopic composition of precipitation, and $t$ is the MAT (Table 1).

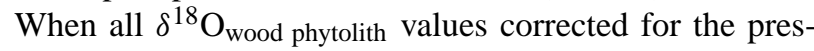
ence of quartz are taken into account, no relationship be-

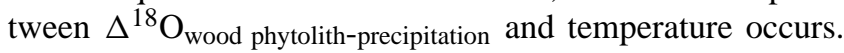
When values from the leeward transect of Bartle Frere are excluded a modest correlation $(\mathrm{p}$-value $<0.05)$ appears (Fig. 5):

$\Delta^{18} \mathrm{O}_{\text {wood phytolith-precipitation }}=-0.4( \pm 0.2) t+46( \pm 3)$,

with $R^{2}=0.4$, p-value $=0.037, n=12$.

When $\delta^{18} \mathrm{O}_{\text {silica }}$ values (excepted Bartle Frere values) are corrected for the presence of quartz and grass phytoliths the obtained relationship is close to Eq. (12) (Fig. 6):

$\Delta^{18} \mathrm{O}_{\text {wood phytolith-precipitation }}=-0.4( \pm 0.2) t+47( \pm 3)$,

with $R^{2}=0.4$, p-value $=0.027, n=12$ or additional correction for palm phytoliths especially concerns two samples (\#9 and \#33). The obtained relationship changes slightly (Fig. 6):

$\Delta^{18} \mathrm{O}_{\text {wood phytolith-precipitation }}=-0.5( \pm 0.2) t+48( \pm 4),(14)$ with $R^{2}=0.35$, p-value $=0.044, n=12$.

Finally, whether corrections for the presence of grass and palm phytoliths are made or not on $\delta^{18} \mathrm{O}_{\text {silica }}$ values, 

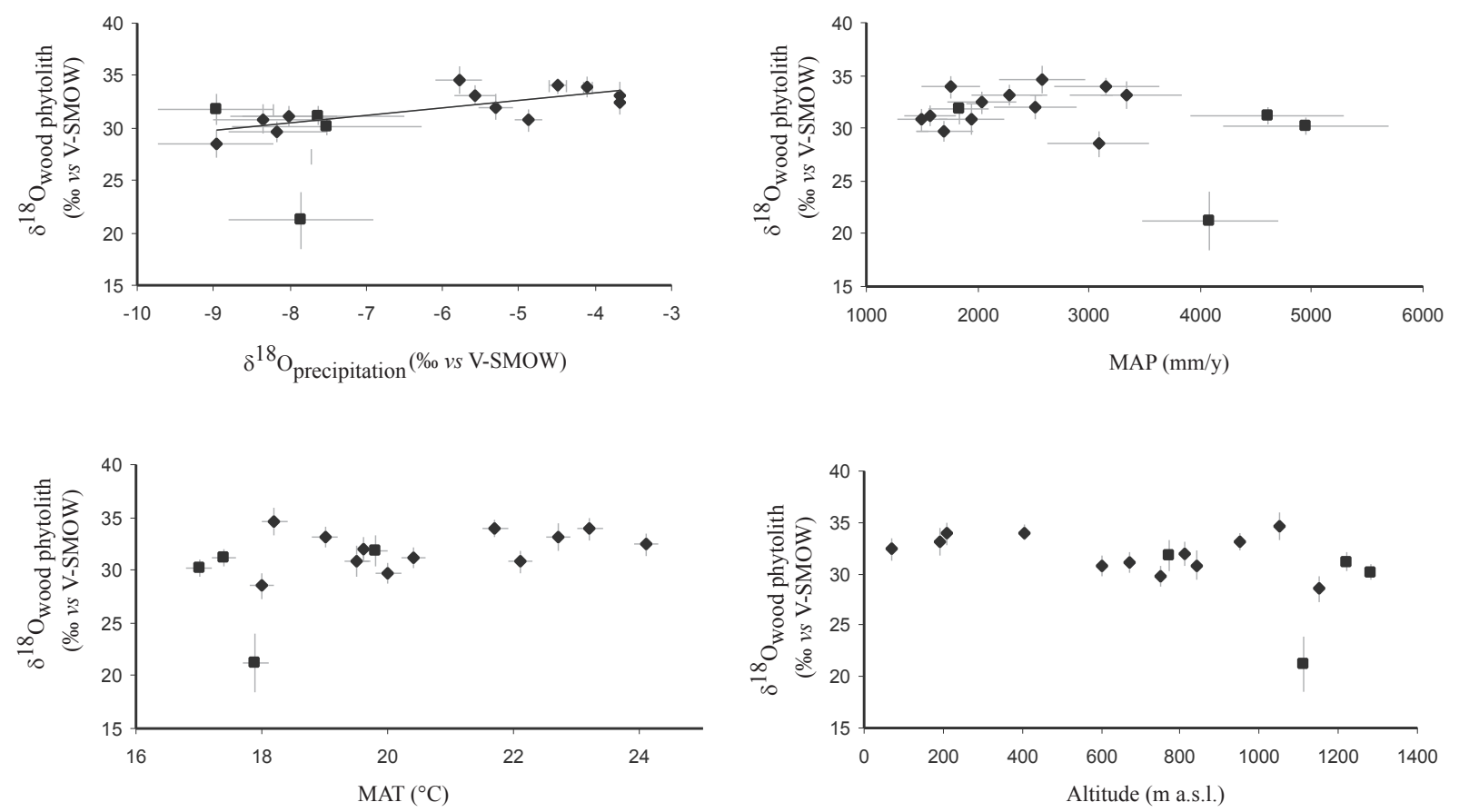

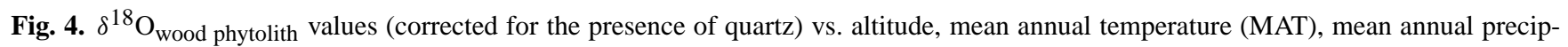

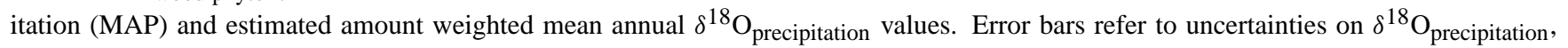

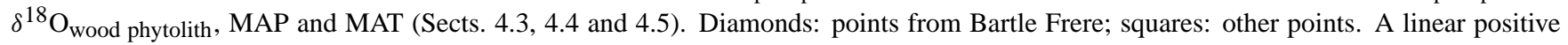
correlation appears between $\delta^{18} \mathrm{O}_{\text {wood phytolith }}$ and $\delta^{18} \mathrm{O}_{\text {precipitation values }}\left(R^{2}=0.5\right)$ when points from Bartle Frere transect (squares) are excluded.

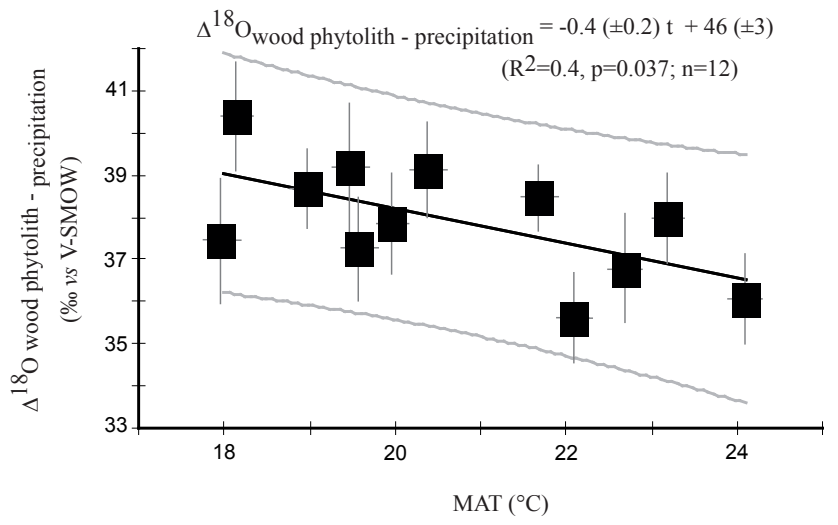

Fig. 5. Empirical relationship between $\Delta^{18} \mathrm{O}_{\text {wood phytolith-precipitation }}$ value and mean annual atmospheric temperature (MAT) obtained for the three windward transects. Grey lines: associated uncertainties (Tables 1 and 2) and limits of the $95 \%$ confidence interval.

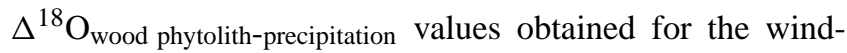
ward transects show negative linear relationships with MAT, expressed by close mean temperature coefficients ranging from $-0.4( \pm 0.2)$ to $-0.5( \pm 0.2) \%{ }^{\circ} \mathrm{C}^{-1}$ and $y$-intercept ranging from 46 to $48( \pm 4) \%$ (Fig. 6). These relationships are in the range of fractionation factor equations previously

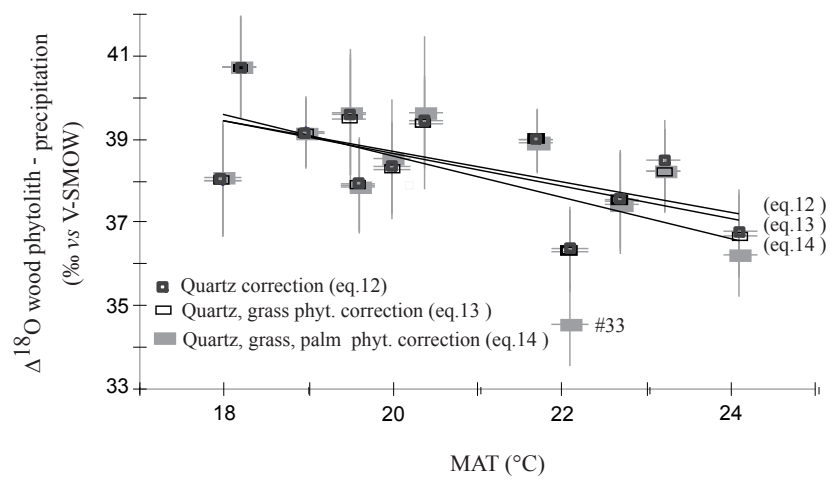

Fig. 6. Impact of non-wood phytolith corrections: relationships be-

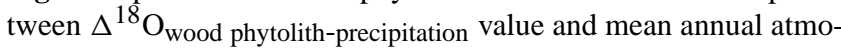
spheric temperature (MAT) obtained for the three windward transects and depending on non-wood phytolith corrections (Table 3 ). Cf. text for Eqs. (1)-(3).

measured for different silica-water couples (Clayton et al., 1972; Matsuhisa et al., 1979; Juillet-Leclerc and Labeyrie, 1987; Sharp and Kirschner, 1994; Shemesh et al., 1992; Shahack-Gross et al., 1996; Brandriss et al., 1998; Moshen et al., 2005; Dodd and Sharp, 2010). For more clarity and because corrections for grass an palm phytoliths may 


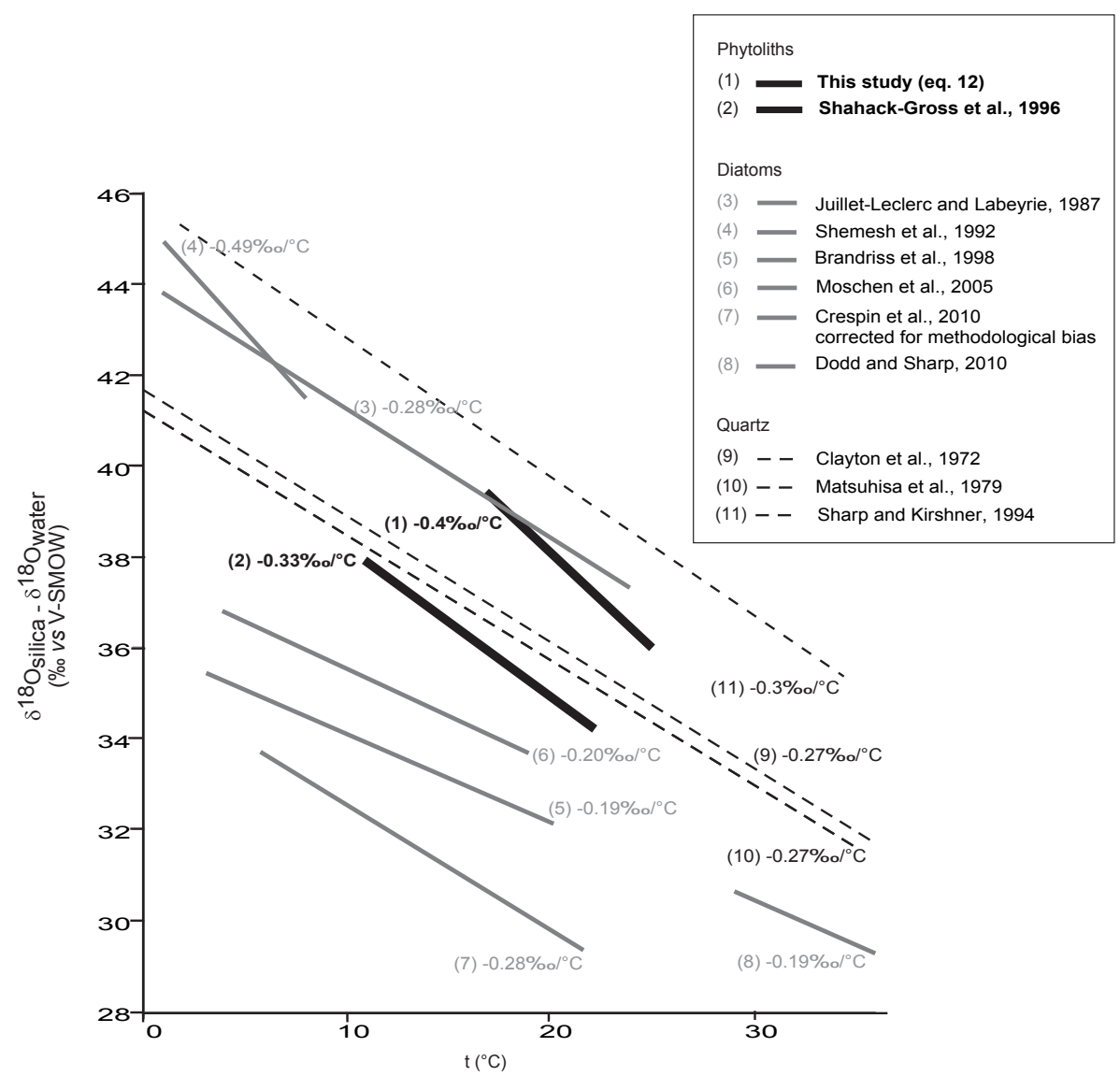

Fig. 7. Comparison of the thermo-dependant relationships expressed as $1000 \ln \alpha \sim\left[\delta^{18} \mathrm{O}_{\text {silica }}-\delta^{18} \mathrm{O}_{\mathrm{water}}\right]\left(\%\right.$ vs. VSMOW) $=\mathrm{at}\left({ }^{\circ} \mathrm{C}\right)+b$ obtained for phytolith-water, diatom-water and quartz-water couples.

be overestimated (cf. Sect. 4.4) $\delta^{18} \mathrm{O}_{\text {wood phytolith values ob- }}$ tained after quartz correction are discussed below.

\section{Discussion}

\subsection{The obtained temperature-dependant relationship: comparison with previous studies}

Equation (12) can be further compared with the temperaturedependant relationships previously published for different silica-water couples (Fig. 7).

Regarding temperature coefficients, Fig. 7 indicates that the $-0.4( \pm 0.2) \% 0^{\circ} \mathrm{C}^{-1}$ value obtained from Eq. (12) is close to the value obtained for harvested grass phytoliths $\left(-0.33 \% 0^{\circ} \mathrm{C}^{-1}\right.$ recalculated from Shahack-Gross et al. (1996) and natural quartz $\left(-0.30 \% 0^{\circ} \mathrm{C}^{-1}\right.$, Sharp and Kirschner, 1994). The coefficient is in the range obtained for fossil diatoms (from -0.28 to $-0.49 \%{ }^{\circ} \mathrm{C}^{-1}$, Juillet-Leclerc and Labeyrie, 1987; Shemesh et al., 1992), slightly larger than the value experimentally obtained for high temperature quartz $\left(-0.24\right.$ to $-0.27 \%{ }^{\circ} \mathrm{C}^{-1}$; Clayton et al., 1972;
Matsuhisa et al., 1979), an $\%{ }^{\circ} \mathrm{C}^{-1}$, Brandriss et al., 1998; Moshen et al., 2005; Dodd and Sharp, 2010; Crespin et al., 2010).

If we focus on the entire temperature-dependant relationships (fractionation lines), Fig. 7 recalls that there is no uniform relationship for the different silica-water couples. Several factors were previously suggested to account for these discrepancies: diatom frustules that show higher dissolution rate than that of phytoliths (Fraysse et al., 2009) may have been subject to early diagenesis which could have impacted their isotopic composition after deposition (Schmidt et al., 2001; Dodd and Sharp, 2010); approximations of temperature and $\delta^{18} \mathrm{O}_{\text {water value may have led to uncertainties on }}$

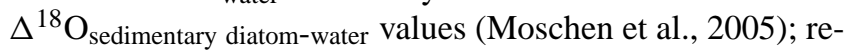
crystallization during experimental high temperature quartzwater exchange may have led to kinetic effects and lowered obtained $\Delta^{18} \mathrm{O}_{\text {quartz-water values (Sharp and Kirschner, }}$ 1994). The extent of these effects are still to be assessed. At the same time, Fig. 7 indicates that the line obtained from Eq. (12) is located in between the ones obtained for natural quartz (Sharp and Kirschner, 1994) and sedimentary diatoms (Juillet-Leclerc and Labeyrie, 1987; Shemesh et al., 
1992) and the ones obtained for grass phytoliths (ShahackGross et al., 1996), fresh water diatoms (Brandriss et al., 1998; Moschen et al., 2005; Dodd and Sharp, 2010; Crespin et al., 2010) and values extrapolated from the high temperature quartz-water fractionation (Clayton et al., 1972; Matshuhisa et al., 1979). For the considered temperature range, our $\delta^{18} \mathrm{O}_{\text {precipitation }}$ estimates (from Eq. 12) are lower by only 0.2 to $0.9 \%$ o than estimates using the fractionation relationship from Juillet-Leclerc and Labeyrie (1987). They are lower by 1.5 to $2.2 \%$ o than estimates using the fractionation relationship from Sharp and Kirschner (1994) and higher by 2.5 to $3.2 \%$ o than estimates using the fractionation relationship from Shahack-Gross et al. (1996). The relative shift to harvested grass phytoliths may result from the uncertainties associated with both relationships. This shift can also be explained if calculated $\Delta^{18} \mathrm{O}_{\text {wood phytolith-precipitation values are }}$ higher than actual $\Delta^{18} \mathrm{O}_{\text {wood phytolith-forming water values, due }}$ to evaporative ${ }^{18} \mathrm{O}$ enrichment of the soil water absorbed by roots. This may occur if a significant part of the water comes from the first 10s of centimeters of soil during the dry and more evaporative season. However, a greening during the dry season, when it occurs, involves rainforest tree roots' capacity for absorbing non- ${ }^{18} \mathrm{O}$ enriched deep soil water rather than shallow water (Huete et al., 2006). Additionally, although biased estimations of $\delta^{18} \mathrm{O}_{\text {precipitation and/or }}$ discrepancies between $\delta^{18} \mathrm{O}_{\text {precipitation }}$ and $\delta^{18} \mathrm{O}_{\text {soil water may }}$ have occurred, they should be reproducible in order to explain systematic shifts of several \%o, which is rather unlikely.

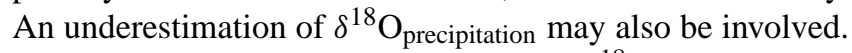
Although agreement between estimated $\delta^{18} \mathrm{O}_{\text {precipitation }}$ and measured $\delta^{18} \mathrm{O}_{\text {precipitation values at Malanda and Walkamine }}$ support the accuracy of our estimations, obtaining long term $\delta^{18} \mathrm{O}_{\text {precipitation }}$ and/or $\delta^{18} \mathrm{O}_{\text {soil water }}$ records (rather than direct measurements only instructive for short term hydrological conditions) for the studied area would help to further verify this accuracy. Finally, superficial dissolution of phytoliths in litter and soil (Alexandre et al., 1999) may also lead to slight ${ }^{18} \mathrm{O}$ enrichment as the lighter isotope, forming weaker bonds and having a higher diffusion velocity than the heavier isotope, goes preferentially to the liquid phase. Dissolution figures are difficult to detect on the granulated surface of the globular granulate phytolith type which prevents verifying the later hypothesis.

\section{2 $\delta^{18} \mathrm{O}_{\text {wood phytolith }}$ values obtained from the leeward Bartle Frere transect}

Data obtained from Bartle Frere transect did not follow the above relationship (Eq. 12), due to particularly low

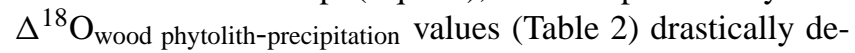
creasing with elevation in contrast to a low temperature gradient (Table 1). Several points are discussed below to account for this discrepancy: (1) a low temperature gra-

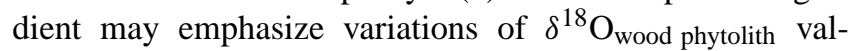
ues in relation to local environmental changes (e.g. soil evaporation, depth of water uptake, phytolith production), but would unlikely explain a shift as high as $8-9 \% 0^{\circ} \mathrm{C}^{-1}$ in $\delta^{18} \mathrm{O}_{\text {wood phytolith }}$ and $\Delta^{18} \mathrm{O}_{\text {wood phytolith-precipitation values; }}$ (2) the four highest sites of the Bartle Frere transect are covered by a cloud forest characterized by cloud striping (McJannete et al., 2007a,b). As previously noted, cloud striping may increase the inland isotopic gradient, enhance the cumulative rainout of ${ }^{18} \mathrm{O}$ depletion in air masses and decrease $\delta^{18} \mathrm{O}_{\text {precipitation values. However, cloud forest sites }}$ of the windward Mt. Edith transect do not show unexpect-

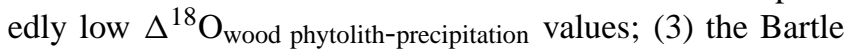
Frere transect diverges from the three other transects in that it is located leeward relative to the S-E trade winds. Potential $\delta^{18} \mathrm{O}_{\text {precipitation }}$ underestimation at leeward sites would imply lower $\Delta^{18} \mathrm{O}_{\text {wood phytolith-precipitation values and cannot }}$ account for the discrepancy. N-W monsoonal winds and cyclones with westerly tracks may contribute to precipitation on the N-W slope of Bartle Frere South Peak to a greater extent than on slopes oriented windward. The associated high amount effect (Nott et al., 2007) would decrease the $\delta^{18} \mathrm{O}_{\text {precipitation value (and increase associated }}$

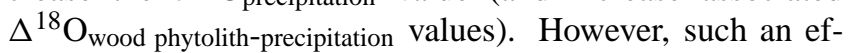
fect would likely impact the whole slope and cannot account

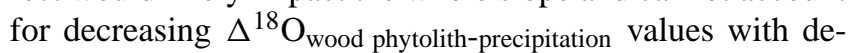
creasing altitude; (4) the Bartle Frere slope may be subject to higher rain shadow effect than the one taken into account in Eq. (2), which may lead to overestimate $\delta^{18} \mathrm{O}_{\text {precipitation val- }}$ ues all the more so altitude decreases. In the literature, the only $\delta^{18} \mathrm{O}_{\text {precipitation }}$ measured value obtained from a leeward tropical site was about $2 \%$ lighter than the one expected for a windward site of similar altitude (Gonfiantini et al., 2001).

Finally, without further data, potential combined impacts of canopy interception, storms and rain shadow effects on $\delta^{18} \mathrm{O}_{\text {precipitation values are difficult to assess but are rather in- }}$ teresting tracks to investigate in a near future.

\subsection{Implications for paleoenvironmental reconstructions}

In the absence of a uniform temperature-dependant relationship for different silica-water couples, the use of one or another fractionation equation for reconstructing precise values for $\delta^{18} \mathrm{O}_{\text {forming water }}$ and temperature from fossil samples appears subject to caution. On the other hand, the small range of empirical temperature coefficients (from 0.2 to $0.5 \% 0^{\circ} \mathrm{C}^{-1}$ ) supports their use for reconstructing, from continuous fossil sequences, relative changes in $\delta^{18} \mathrm{O}_{\text {forming water }}$ and temperature. Consistence of the empirical temperature coefficient obtained in the present study $\left(-0.4( \pm 0.2) \% 0^{\circ} \mathrm{C}^{-1}\right)$ highlights the reliability of soil top phytolith assemblages from rainforests of northeast Queensland to reflect changes in MAT and $\delta^{18} \mathrm{O}_{\text {precipitation. If no }}$ significant fractionation occurs when phytoliths are exported and buried, continuous fossil phytolith sequences from lakes in northeast Queensland can be used for reconstructing past 
relative changes in $\delta^{18} \mathrm{O}_{\text {soil water }}$ and $\delta^{18} \mathrm{O}_{\text {precipitation values }}$ (when both isotopic compositions are assumed to be close) and/or in MAT values. Given the large uncertainties ob-

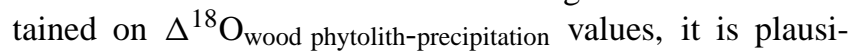
ble to expect reproducible uncertainties of several \%o and several ${ }^{\circ} \mathrm{C}$ on reconstructed changes in $\delta^{18} \mathrm{O}_{\text {soil water and/or }}$ $\delta^{18} \mathrm{O}_{\text {precipitation values, and MAT values. Moreover, given }}$ the low amount of phytoliths recovered from soils and sediments, we expect the time resolution from sedimendary phytolith records to be limited to hundreds of years. However, such large uncertainties and low time resolution are still sufficient for investigating significant terrestrial changes that occurred during the Quarternary glacial/interglacial transitions. If the range of temperature changes can be constrained by other proxies, such as pollen transfer functions, reconstruction of relative changes in $\delta^{18} \mathrm{O}_{\text {soil water values using }}$

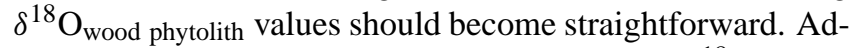
ditionally, the association of morphological and $\delta^{18} \mathrm{O}$ analyses on similar tropical forest phytolith assemblages should allow one to assess whether past forest dynamics were or were not synchronous with climate changes. At least a comparison of terrestrial $\delta^{18} \mathrm{O}$ records from tropical forest phytolith assemblages with deep-sea reference curves should help to further investigate the relationship between global oceanic transgression/regression phases (e.g. revealed by $\delta^{18} \mathrm{O}_{\text {benthic foraminifera }}$ records) and local changes in the water cycle (revealed by $\delta^{18} \mathrm{O}_{\text {phytolith }}$ records).

\section{Conclusions}

The obtained empirical temperature-dependant relationship Eq. (12) suggests that top phytolith assemblages from rainforests of northeast Queensland reflect changes in MAT and

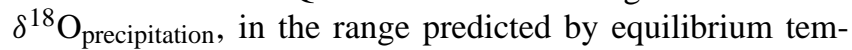
perature coefficients previously published for quartz, diatoms and harvested grass phytoliths. This, despite the various unknowns introduced when estimating $\delta^{18} \mathrm{O}_{\text {precipitation values }}$ and the large uncertainties on $\delta^{18} \mathrm{O}_{\text {wood phytolith values. The }}$ consistency supports the reliability of $\delta^{18} \mathrm{O}_{\text {wood phytolith sig- }}$ natures for recording changes in mean annual $\delta^{18} \mathrm{O}_{\text {soil water }}$ values (which are assumed to be equivalent to the weighted annual $\delta^{18} \mathrm{O}_{\text {precipitation values in rainforests environments) }}$ and MAT, provided these changes were several \%o and/or several ${ }^{\circ} \mathrm{C}$ in magnitude. Morphological phytolith analysis of Quaternary continuous sedimentary sequences from the Western Australo-Pacific area should help to select rainforest phytolith assemblages suitable for $\delta^{18} \mathrm{O}$ analysis. The combination of both methods should provide simultaneous insights regarding rainforest dynamics and climate change.
Acknowledgements. This work was conducted during the thesis of J. Crespin PhD (2004-2008) and was partially supported by the Stable Isotope Lab at CEREGE and the French program ECLIPSE. We thank the Sustainable Ecosystems group at the Tropical Forest Research Center (CSIRO) of Atherton who helped us to organize the field trip and who provided the ANUCLIM data. $\delta^{18} \mathrm{O}_{\text {precipitation values measured for Malanda and Walkamine were }}$ made available to us by P. G. Cooks and Andrew Herczeg (CSIRO Land and Water). Errors on MAT an MAP values generated by the ANUCLIM software were assessed thanks to Michael Hutchinson (ANU). We also thank C. Paillès and C. Vallet-Coulomb (CEREGE) for respectively providing and analyzing the CIE waters, and J. J. Motte (mapping, CEREGE). This work benefited from the comments of two anonymous reviewers.

Edited by: D. Fleitmann

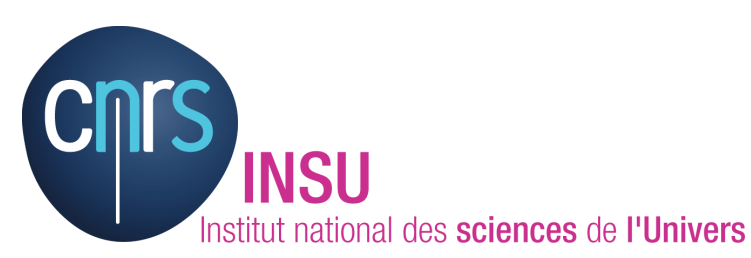

The publication of this article is financed by CNRS-INSU.

\section{References}

Alexandre, A., Meunier, J. D., Colin, F., and Koud, J. M.: Plant impact on the biogeochemical cycle of silicon and related weathering processes, Geochim. Cosmochim. Acta, 61, 677-682, 1997.

Alexandre, A., Meunier, J. D., Lézine, A. M., Vincens, A., and Schwartz, D.: Phytoliths: indicators of grassland dynamics during the Late Holocene in intertropical Africa, Palaeogeogr. Palaeocl., 136, 213-229, 1998.

Alexandre, A., Meunier, J. D., Mariotti, A., and Soubies, F.: Late Holocene paleoenvironmental record from a latosol at Salitre (Southern Central Brazil): phytolith and carbon isotope evidence, Quaternary Res., 51, 187-194, 1999.

Alexandre, A., Sonzogni, C., Basile, I., Sylvestre, F., Parron, C., Meunier, J. D., and Colin, F.: Oxygen isotope analyses of fine silica grains using laser-extraction technique: comparison with oxygen isotope data obtained from ion microprobe analyses and application to quartzite and silcrete cement investigation, Geochim. Cosmochim. Acta, 70, 2827-2835, 2006.

Barboni, D., Bremond, L., and Bonnefille, R.: Comparative study of modern phytolith assemblages from inter-tropical Africa, Palaeogeogr. Palaeocl., 246, 454-470, 2007.

Blatt, H.: Oxygen isotopes and the origin of quartz, J. Sediment. Petrol., 57, 373-377, 1986.

Bowen, G. J. and Wilkinson, B.: Spatial distribution of $\delta^{18} \mathrm{O}$ in meteoric precipitation, Geology, 30, 315-318, 2002.

Boyd, W. E., Lentfer, C. J., and Parr, J.: Interactions between human activity, volcanic eruptions and vegetation during the Holocene at Garua and Numundo, West New Britain, PNG, Quaternary Res., 64, 384-398, 2005. 
Brandriss, M. E., O’Neil, J. R., Edlund, M. B., and Stoermer, E. F.: Oxygen isotope fractionation between diatomaceous silica and water, Geochim. Cosmochim. Acta, 62, 1119-1125, 1998.

Bremond, L., Alexandre, A., Peyron, O., and Guiot, J.: Grass water stress estimated from phytoliths in West Africa, J. Biogeogr., 32, 11-32, 2005a.

Bremond, L., Alexandre, A., Hely, C., and Guiot, J.: A phytolith index as a proxy of tree cover density in tropical areas: calibration with Leaf Area Index along a forest-savanna transect in southeastern Cameroon, Global Planet. Change, 45, 277-293, 2005b.

Bremond, L., Alexandre, A., Peyron, O., and Guiot, J.: Grassland biomes estimated from phytoliths in West Africa, J. Biogeogr., 35, 2039-2048, 2008a.

Bremond, L., Alexandre, A., Wooller, M. J., Hély, C., Williamson, D., Schäfer, P. A., Majule, A., and Guiot, J.: Phytolith indices as proxy of grass subfamilies dominance on tropical mountains from three sites in East Africa: Mt Kenya (Kenya), Mt Rungwe and Lake Masoko (Tanzania), Global Planet. Change, 61, 209224, 2008b.

Canadell, J., Jackson, R. B., Ehleringer, J. R., Mooney, H. A., Sala, O. E., and Schulze, E.-D.: Maximum rooting depth of vegetation types at the global scale, Oecologia, 108, 583-595, 1996.

Cary, L., Alexandre, A., Meunier, J. D., Boeglin, J. L., and Braun, J. J.: Contribution of phytoliths to the suspended load of biogenic silica in the Nyong basin rivers (Cameroon), Biogeochemistry, 74, 101-114, 2005.

Chapligin, B., Leng, M., Webb, E., Alexandre, A., Dodd, J., Faure, K., Ijiri, A., Lücke, A., Shemesh, A., Abelmann, A., Herzschuh, U., Longstaffe, F., Meyer, H., Moschen, R., Okazaki, Y., Rees, N. H., Sharp, Z., Sloane, H. J., Sonzogni, C., Swann, G., Sylvestre, F., Tyler, J., and Yam, R.: Interlaboratory comparison of oxygen isotopes from biogenic silica, submitted to Geochim. Cosmochim. Acta, 2012.

Clayton, R. N., O’Neil, J. R., and Mayeda, T. K.: Oxygen isotope exchange between quartz and water, J. Geophys. Res., 77, 30573067, 1972.

Crespin, J., Alexandre, A., Sylvestre, F., Sonzogni, C., Paillès, C., and Garreta, V.: IR-laser-extraction technique adapted to oxygen isotopes analysis of small biogenic silica samples, Anal. Chem., 80, 2372-2378, 2008.

Crespin, J., Sylvestre, F., Alexandre, A., Sonzogni, C., Paillès, C., Perga, M. E.: Re examination of the temperature-dependent relationship between $\delta^{18} \mathrm{O}_{\text {diatoms }}$ and $\delta^{18} \mathrm{O}_{\text {lake water for Lake }}$ Annecy (France). Implications for palaeoclimatic applications, J. Paleolimnol., 44, 547-557, doi:10.1007/s10933-010-9436-2, 2010.

Dansgaard, W.: Stable isotopes in precipitation, Tellus, 4, 436-468, 1964.

Danzeglocke, U., Jöris, O., and Weninger, B.: CalPal-2007online, http://www.calpal-online.de/, last access: 27 October 2011.

DASETT: Nomination of Wet Tropical Rainforests of North-east Australia by the Government of Australia for inclusion in the World Heritage List, Department of Arts, Sports, the Environment, Tourism and Territories, 31 pp., 1986.

Dayem, K. E., Molnar, P., Battisti, D. S., and Roe, G. H.: Lessons learned from oxygen isotopes in modern precipitation applied to interpretation of speleothem records of paleoclimate from eastern Asia, Earth Planet. Sc. Lett., 295, 219-230, 2010.
Dodd, J. P. and Sharp, Z. D.: A laser fluorination method for oxygen isotope analysis of biogenic silica and a new oxygen isotope calibration of modern diatoms in freshwater environments, Geochim. Cosmochim. Acta, 74, 1381-1390, 2010.

Eslinger, E., Mayer, L. M., Durst, T. L., Hower, J., and Savin, S. M.: An X-ray technique for distinguishing between detrital and secondary quartz in the fine-grained fraction of sedimentary rocks, J. Sediment. Petrol., 43, 540-543, 1973.

Flanagan, L. B., Bain, J. F., and Ehleringer, J. R.: Stable oxygen and hydrogen isotope composition of leaf water in $\mathrm{C}_{3}$ and $\mathrm{C}_{4}$ plant species under field conditions, Oecologia, 88, 394-400, 1991.

Fraysse, F., Pokrovsky, O. S., Schott, J., and Meunier, J. D.: Surface chemistry and reactivity of plant phytoliths in aqueous solutions, Chem. Geol., 258, 197-206, 2009.

Fredlund, G. and Tieszen, L. T.: Modern phytolith assemblages from the North American Great Plains, J. Biogeogr., 21, 321335, 1994.

Fricke, H. C. and O'Neil, J. R.: The correlation between ${ }^{18} \mathrm{O} /{ }^{16} \mathrm{O}$ ratios of meteoric water and surface temperature: its use in investigating terrestrial climate change over geologic time, Earth Planet. Sc. Lett., 170, 181-196, 1999.

Garlick, G. D. and Epstein, S.: Oxygen isotope ratios in coexisting minerals of regionally metamorphosed rocks, Geochim. Cosmochim. Acta, 31, 181-214, 1967.

Gat, J. R.: Atmospheric water balance-the isotopic perspective, Hydrol. Process., 14, 1357-1369, 2000.

Gat, J. R. and Matsui, E.: Atmospheric water balance in the Amazon basin: an isotopic evapotranspiration model, J. Geophys. Res., 96, 13179-13188, 1991.

Gat, J. R., Mook, W. G., and Meijer, A. J.: Environmental Isotopes in the hydrological cycle, in: Principles and applications IHP-V Technical Documents in Hydrology, 39, UNESCO-IAEA, 2001.

Genty, D., Blamart, D., Ouahdi, R., Gilmour, M., Baker, A., Jouzel, J., and Van-Exter, S.: Precise dating of Dansgaard-Oeschger climate oscillations in western Europe from stalagmite data, Nature, 421, 833-837, 2003.

Girard, J. P., Freyssinet, P., and Chazot, G.: Unraveling climatic changes from intraprofile variation in oxygen and hydrogen isotopic composition of goethite and kaolinite in laterites: an integrated study from Yaou, French Guiana, Geochim. Cosmochim. Acta, 64, 409-426, 2000.

Godfred-Spenning, C. R. and Reason, C. J. C.: Interannual variability of lower troposheric moisture transport during the australian monsoon, Int. J. Climatol., 22, 509-532, 2002.

Gonfiantini, R., Roche, M. A., Olivry, J. C., Fontes, J. C., and Zuppi, G. M.: The alitude effect on the isotopic composition of tropical rains, Chem. Geol., 181, 147-167, 2001.

Graham, C. M., Valley, J. W., and Winter, B. L.: Ion microprobe analysis of ${ }^{18} \mathrm{O} /{ }^{16} \mathrm{O}$ in authigenic and detrital quartz in the St. Peter Sandstone, Michigan Basin and Wisconsin Arch, USA: contrasting diagenetic histories, Geochim. Cosmochim. Acta, 60, 5101-5116, 1996.

Haberle, S. G.: A 23,000-yr pollen record from Lake Euramoo, Wet Tropics of NE Queensland, Australia, Quaternary Res., 64, 343356, 2005.

Houlder, D., Hutchinson, M., Nix, H., and McMahon, J.: ANUCLIM User's Guide, Australian National University, Canberra, 2000. 
Hsieh, J. C. C., Chadwick, O. A., Kelly, E. F., and Savin, S. M.: Oxygen isotopic composition of soil water: quantifying evaporation and transpiration, Geoderma, 82, 269-293, 1998.

Huete, A. R., Didan, K., Shimabukuro, Y. E., Ratana, P., Saleska, S. R., Hutyra, L. R., Yang, W., Nemani, R. R., and Myneni, E.: Amazon rainforests green-up with sunlight in dry season, Geophys. Res. Lett., 33, L06405, doi:10.1029/2005GL025583, 2006.

Hutchinson, M. F.: The application of thin plate smoothing splines to continent-wide data assimilation, in: Data Assimilation Systems, edited by: Jasper, J. D., Bureau of Meteorology Research Report No. 27, Melbourne, 104-113, 1991.

Hutchinson, M. F.: Interpolating mean rainfall using thin plate smoothing splines, Int. J. Geogr. Inf. Syst., 9, 385-403, 1995.

Hutley, L. B., Doley, D., and Yates, D. J.: Water balance of an Australian subtropical rainforest at altitude: the ecological and physiological significance of intercepted cloud and fog, Aust. J. Bot., 45, 311-329, 1997.

Jenkinson, D. J. and Rayner, J. H.: The turnover of soil organic matter in some of the Rothamsted classical experiments, Soil Sci., 123, 298-305, 1977.

Juillet-Leclerc, A. and Labeyrie, L.: Temperature dependence of the oxygen isotopic fractionation between diatom silica and water, Earth Planet. Sc. Lett., 84, 69-74, 1987.

Kelly, E. F.: Methods for extracting opal phytoliths from soils and plant material, Internal Report, Colorado State University, Fort Collins, 1990.

Kershaw, A. P., Bretherton, S. C., and van der Kaars, S.: A complete pollen record of the last 230 ka from Lynch's Crater,north-eastern Australia, Palaeogeogr. Palaeocl., 251, 23-45, 2007.

Kondo, R., Childs, C., and Atkinson, I.: Opal phytoliths of New Zealand, Manaaki Whenua Press, 85 pp., 1994.

Labeyrie, L. and Juillet, A.: Oxygen isotopic exchangeability of diatom valve silica; interpretation and consequences for paleoclimatic studies, Geochim. Cosmochim. Acta, 46, 967-975, 1982.

Lachniet, M. S. and Patterson, W. P.: Stable isotope values of Costa Rican surface waters, J. Hydrol., 260, 135-150, 2002.

Lachniet, M. S. and Patterson, W. P.: Oxygen isotope values of precipitation and surface waters in northern Central America (Belize and Guatemala) are dominated by temperature and amount effects, Earth Planet. Sc. Lett., 284, 435-446, 2009.

Lecuyer, C., Reynard, B., and Martineau, F.: Stable isotope fractionation between mollusc shells and marine waters from Martinique Island, Chem. Geol., 213, 293-305, 2004.

Leng, M. J. and Barker, P. A.: A review of the oxygen isotope composition of lacustrine diatom silica for paleoclimate reconstruction, Earth Sci. Rev., 75, 5-27, 2006.

Lentfer, C. and Torrence, R.: Holocene volcanic activity, vegetation succession, and ancient human land use: unraveling the interactions on Garua Island, Papua New Guinea, Rev. Palaeobot. Palynol., 143, 83-105, 2007.

Liu, W., Li, X., Zhang, L., An, Z., and Xu, L.: Evaluation of oxygen isotopes in carbonate as an indicator of lake evolution in arid areas: The modern Qinghai Lake, Qinghai-Tibet Plateau, Chem. Geol., 268, 126-136, 2009.

Longinelli, A., Anglesio, E., Flora, O., Iacumin, P., and Selmo, E.: Isotopic composition of precipitation in Northern Italy: Reverse effect of anomalous cliamtic events, J. Hydrol., 329, 471-476, 2006.
Madella, M., Alexandre, A., and Ball, T.: ICPN Working Group (2005) International Code for Phytolith Nomenclature 1.0, Ann. Bot.-London, 96, 253-260, 2005.

Martinelli, L. A., Victoria, R. L., Sternberg, L. S. L., Ribeiro, A., and Moreira, M. Z.: Using stable isotopes to determine sources of evaporated water to the atmosphere in the Amazon Basin, J. Hydrol., 183, 191-204, 1996.

Matsuhisa, Y., Goldsmith, J. R., and Clayton, R. N.: Oxygen isotopic fractionation in the system quartz-albite-anorthite-water, Geochim. Cosmochim. Acta, 43, 1131-1140, 1979.

McJannet, D., Wallace, J., and Reddell, P.: Precipitation interception in Australian tropical rainforests: I. Measurment of stemflow, throughfall and cloud interception, Hydrol. Process., 21, 1692-1702, 2007a.

McJannet, D., Wallace, J., and Reddell, P.: Precipitation interception in Australian tropical rainforests: I. Altitudinal gradient of cloud interception, stemflow, throughfall and interception, Hydrolo. Process., 21, 1703-1718, $2007 \mathrm{~b}$.

McMahon, J. P., Hutchinson, M. F., Nix, H. A., and Ord, K. D.: ANUCLIM user's guide, version 1, Centre for Resource and Environmental Studies, Australian National University, Canberra, 1995.

Moschen, R., Lücke, A., and Schleser, G. H.: Sensitivity of biogenic silica oxygen isotopes to changes in surface water temperature and paleoclimatology, Geophys. Res. Lett., 32, L07708, doi:10.1029/2004GL022167, 2005.

Moss, P. T. and Kershaw, A. P.: The last glacial cycle from the humid tropics of northeastern Australia: comparison of a terrestrial and a marine record, Palaeogeogr. Palaeocl., 155, 155-176, 2000.

Mulholland, S. C.: Phytoliths shape frequencies in North Dakota grasses: A comparison to general patterns, J. Archaeol. Sci., 16, 489-511, 1989.

Neumann, K., Fahmy, A., Lespez, L., Ballouche, A., and Huysecom, E.: The Early Holocene palaeoenvironment of Ounjougou (Mali): phytoliths in a miltiproxy context, Palaeogeogr. Palaeocl., 276, 87-106, 2009.

Njitchoua, R., Sigha-Nkamdjou, L., Dever, L., Marlin, C., Sighomnou, D., and Nia, P.: Variations of the stable isotopic composition of rainfall events from the Cameroon rainforest, Central Africa, J. Hydrol., 223, 17-23, 1999.

Nott, J., Haig, J., Neil, H., and Gillieson, D.: Greater frequency variability of land falling tropical cyclones at centennial compared to seasonal and decadal scales, Earth Planet. Sc. Lett., 255, 367-372, 2007.

Ometto, J. P. H., Flanagan, L. B., Martinelli, L. A., and Ehrleringer, J. R.: Oxygen isotope ratios of waters and respired $\mathrm{CO}_{2}$ in Amazonian forest and pasture ecosystems, Ecol. Appl., 15, 58-70, 2005.

Parton, W. J., Schimel, D. S., Cole, C. V., and Ojima, D. S.: Analysis of factors controlling soil organic matter levels in Great Plains grasslands, Soil Sci. Soc. Am. J., 51, 1173-1179, 1987.

Perry, C. C. and Keeling-Tucker, T.: Biosilicification: the role of organic matrix in structure control, J. Biol. Inorg. Chem., 5, 537550, 2000.

Piperno, D. R.: Phytoliths: a comprehensive guide for archaeologists and paleoecologists, Altamira Press, Lanham, p. 238, 2006. 
Piperno, D. R. and Becker, P.: Vegetational history of a site in the central Amazon Basin derived from phytolith and charcoal records from natural soils, Quaternary Res., 45, 202-209, 1996.

Poage, M. A. and Chamberlain, C. P.: Empirical relationships between elevation and the stable isotope composition of precipitation and surface waters: considerations for studies of paleoelevation change, Am. J. Sci., 301, 1-15, 2001.

Prior, C. A., Carter, J. A., and Rieser, U.: Are phytolith radiocarbon dates reliable?, 10th International Conference on Accelerator Mass Spectrometry, Berkeley, USA, 2005.

Rieser, U. and Wust, R. A. J.: OSL chronology of Lynch's Crater, the longest terrestrial record in NE-Australia, Quatern. Geochronol., 5, 233-236, 2010.

Rieser, U., Carter, J. A., and Prior, C. A.: Phytoliths: a chronometer for the late Quaternary, Poster presented at the INQUA 2007 Conference, Cairns, Australia, July/August 2007.

Rietti-Shatti, M., Yam, R., Karlen, W., and Shemesh, A.: Stable isotope composition of tropical high-altitude fresh-waters on Mt Kenya, Equatorial East Africa, Chem. Geol., 166, 341-350, 2000.

Robertson, A. W., Kirshner, S., Smyth, P., Charles, S. P., and Bates, B. C.: Subseasonal-to-Interdecadal variability of the Australian monsoon over North Queensland, Q. J. Roy. Meteorol. Soc., 131, 1-26, 2005.

Rozanski, K., Araguas-Araguas, L., and Gonfiantini, R.: Isotopic patterns in modern global precipitations, in: Climate change in continental climate records, edited by: Swart, P. K., Lohmann, K. C., Mc Kenzie, J., and Savin, S., American Geophysical Union, Geophys. Monogr., 78, 1-36, 1993.

Runge, F.:The opal phytolith inventory of soils in central Africa - quantities, shapes, classification, and spectra, Rev. Palaeobot. Palynol., 107, 23-53, 1999.

Salati, E., Dall'Ollio, A., Gat, J., and Matsui, E.: Recycling of water in the Amazon basin: an isotope study, Water Resour. Res., 15, 1250-1258, 1979.

Santos, G. M., Southon, J. R., Druffel-Rodriguez, K. C., Griffin, S., and Mazon, M.: Magnesium perchlorate as an alternative water trap in AMS graphite sample preparation: A report on sample preparation at KCCAMS at the University of California, Irvine, Radiocarbon, 46, 165-173, 2004.

Santos, G. M., Alexandre, A., Coe, H. H. G., Reyerson, P. E., Southon, J. R., and De Carvalho, C. N.: The Phytolith ${ }^{14} \mathrm{C}$ puzzle: a tale of background determinations and accuracy tests, Radicarbon, 52-1, 113-128, 2010.

Savin, S. M. and Epstein, S.: The oxygen isotopic compositions of coarse grained sedimentary rocks and minerals, Geochim. Cosmochim. Acta, 34, 323-329, 1970.

Scurfield, G., Anderson, C. A., and Segnit, E. R.: Silica in woody stems, Aust. J. Bot., 22, 211-229, 1974.

Shahack-Gross, R., Shemesh, A., Yakir, D., and Weiner, S.: Oxygen isotopic composition of opaline phytoliths: potential for terrestrial climatic reconstruction, Geochim. Cosmochim. Acta, 60, 3949-3953, 1996.
Sharp, Z. D. and Kirschner, D. L.: Quartz-calcite oxygen isotope thermometry: A calibration based on natural isotopic variations, Geochim. Cosmochim. Acta, 58, 4491-4501, 1994.

Shemesh, A., Charles, C. D., and Fairbanks, R. G.: Oxygen isotopes in Biogenic Silica: Global Changes in Ocean Temperature and Isotopic Composition, Science, 256, 1434-1436, 1992.

Siegenthaler, U. and Oeschger, H.: Correlation of ${ }^{18} \mathrm{O}$ in precipitation with temperature and altitude, Nature, 285, 314-317, 1980.

Strömberg, C. A. E.: Decoupled taxonomic radiation and ecological expansion of open-habitat grasses in the Cenozoic of North America, P. Natl. Acad. Sci., 102, 11980-11984, 2005.

Suppiah, R., Collins, D. A., and Della-Marta, P. M. Observed changes in australian climate, supporting document for: Climate change projections for australia, Technical report, CSIRO Atmospheric Research, Aspendale, Australia, 2001.

Tracey, J. G.: The vegetation of the humid tropical region of North Queensland, CSIRO, 128 pp., 1982.

Twiss, P. C.: Predicted world distribution of C3 and C4 grass phytoliths, in: Phytolith Systematiccs, edited by: Rapp, G. and Mulholand, S. C., Emerging Issues. Adv. Archeol. Mus. Sci. I, 113128, 1992.

Von Grafenstein, U., Erlenkeuser, H., Brauer, A., Jouzel, J., and Johnsen, S. J.: A Mid-European decadal isotope-climate record from 15,500 to 5000 years B.P., Science, 284, 1654-1657, 1999.

Wang, Y., Cheng, H., Edwards, R. L., He, Y., Kong, X., An, Z., Wu, J., Kelly, M. J., Dykoski, C. A., and Li, X.: The Holocene Asian Monsoon: Links to Solar Changes and North Atlantic Climate, Science 308, 854-857, 2005.

Webb, E. A. and Longstaffe, F. J.: The oxygen isotopic compositions of silica phytoliths and plant water in grasses: implications for the study of paleoclimate, Geochim. Cosmochim. Acta, 64, 767-780, 2000.

Webb, E. A. and Longstaffe, F. J.: Climatic influences on the oxygen isotopic composition of biogenic silica in prairie grass, Geochim. Cosmochim. Acta, 66, 1891-1904, 2002.

Webb, E. A. and Longstaffe, F. J.: The relationship between phytolith-and plant water $\delta^{18} \mathrm{O}$ values in grasses, Geochim. Cosmochim. Acta, 67, 1437-1449, 2003.

Webb, E. A. and Longstaffe, F. J.: Identifying the $\delta^{18} \mathrm{O}$ signature of precipitation in grass cellulose and phytoliths: Refining the paleoclimate model, Geochim. Cosmochim. Acta, 70, 2417-2426, 2006.

Webb, J. A. and Golding, S. D.: Geochemical mass-balance and oxygen-isotope constraints on silcrete formation and its paleoclimatic implications in southern Australia, J. Sediment. Res., 68, 981-993, 1998.

Webb, L. J. and Tracey, J. G.: The rainforests of northern Australia, in: Australian vegetation, edited by: Groves, R. H., Cambridge University Press, 87-130, 1994.

Yanes, Y., Romanek, C. S., Delgado, A., Brant, H. A., Noakes, J. E., Alonso, M. R., and Ibanez, M.: Oxygen and carbon stable isotopes of modern land snail shells as environmental indicators from a low-latitude oceanic island, Geochim. Cosmochim. Acta, 73, 4077-4099, 2009. 